\title{
Age-Related Differences in ERP Components during Korean Honorific Sentence Processing Depending on Listener's Social Status and Predicate Agreement
}

\author{
Seon Jeong Oh, Jee Eun Sung \\ Department of Communication Disorders, Graduate School, Ewha Womans University, Seoul, Korea
}

Correspondence: Jee Eun Sung, PhD Department of Communication Disorders, Ewha Womans University, 52 Ewhayeodae-gil, Seodamun-gu, Seoul 03760, Korea

Tel: $+82-2-3277-2208$

Fax: +82-2-3277-2122

E-mail: jeesung@ewha.ac.kr

Received: January 5, 2017

Revised: February 14, 2017

Accepted: February 24, 2017

This work was supported by the Ministry of Education of the Republic of Korea and the National Research Foundation of Korea (NRF2016S1A5B6913884)

This work was supported by Lee Seung Hwan's Scholarship from the Korean Academy of SpeechLanguage Pathology and Audiology in 2016

\begin{abstract}
Objectives: The purpose of this study is to use an event-related potential (ERP) experiment with normally developing young and elderly groups to investigate honorifics processing, a unique linguistic form of the Korean language. Methods: A total of 44 participants (young, 23; elderly, 21) took part in the study. Experimental sentences were made of 3 syntactic words, 'appellation+object+predicate'. According to the high/low social status exhibited in appellation and consistency with predicate final endings, two sentences were formed with a total of 4 experimental conditions. The last verbal word of the presented sentence was the critical word. The electroencephalography was recorded from 32 channels following the International 10-20 system, and mean amplitude was analyzed. Results: The behavioral results showed that the average positive response rate and the response time of the young group were much higher and faster, respectively, than that of the elderly group. The N400 component was observed in a time window of 300-500 ms when the relative social status was inconsistent with its predicate final ending due to pragmatic violations and failure of semantic integration during vocabulary processing. Also, the P600 component was observed in the time window of 500-800 ms due to grammatical abnormality. Conclusion: compared to the young group, delay of sentence process capability during linguistic processing occurs due to the weakened neurological condition of the elderly.
\end{abstract}

Keywords: Aging, Honorifics, ERP, N400, P600, Sentence processing
언어는 민족성과 문화의 다양성을 반영하며 일상생활에서 매우 중요한 기능적 의사소통에 영향을 미친다(Frattali \& Lynch, 1989). 사람은 공유되는 가치관, 의미, 행동 규범을 표현하기 위해서 언어 규칙을 사용한다. 또한 언어를 통해 문화적인 정보를 전달한다. 각 언어의 표현은 교육수준, 경제수준, 사회적 지위, 나이, 문화적 배 경, 성별, 지역 및 국가적 배경, 언어 스타일과 같은 사회.문화적 환 경에 맞춰진다(Kavanagh \& Kennedy, 1992).

예절을 매우 중요시 여기는 사회·문화적 환경을 갖는 한국 사회 는 위계질서가 분명하고 윗사람, 아랫사람에 대한 구분이 뚜렷하 다. 따라서 상대의 직위와 나이, 신분에 맞는 적절한 호칭의 사용이 필수적이며(Wang, 2013), 타인에 대해 존중하여 높여 표현하고, 자 신을 낮추어 표현하는 언어 예절을 가지고 있다. 한국어의 보편적 인 언어 예절은 한국어 문법에 그대로 반영되며 이러한 독특한 언
어 특성은 경어법으로 실현된다. 경어법은 한국 사회에서 매우 중 요한 언어 형식이며 한국어가 가지는 언어 특징을 가장 잘 표현하 는 대표적인 언어 현상이다. 언어 예절을 갖는 한국어의 모든 문장 에서 경어법이 실현된다. 화자가 발화한 문장의 구성 요소 중 경어 법을 실현하는 요소들이 적절하게 선택되면 적합한 문장으로 받 아들여지지만 적절하게 선택되지 않으면 적합한 문장으로 받아들 여지지 않는다. 즉, 화자가 청자에 대한 적절한 경어 표현을 사용하 지 않으면 청자에 대한 언어 예절을 어기게 된다(Kim, 2007). 경어 법은 화자와 청자의 사회·문화적 맥락과 관계를 반영하기 때문에 바로 알아야 화자와 청자의 언어적 관계가 원만하게 유지될 수 있 으며 적절하고 올바른 사용이 무엇보다 중요하다.

발화의 의미 이해는 문맥에 의존하며 선행한 발화 내용, 화자, 청 자의 가치관, 세상지식(world knowledge), 비언어적(extra-linguis- 
tic) 정보가 발화를 이해하는 데 기여한다(Van Berkum, 2009). 상 대방의 사회적 지위에 대한 정보는 발화 처리과정에 영향을 미치는 중요한 비언어적 정보 중에 하나이다. 상대방의 사회적 지위를 반 영하는 언어 형식이 적절하게 사용되지 않으면 수용과정에서 화자 는 잘못된 언어 형식의 사용을 즉시 알아차리게 된다(Jiang, Li, \& Zhou, 2013).

상대의 사회적 지위에 대한 정보는 특정 언어 형식인 경어법으로 나타나게 되며, 한국어에서 경어법의 사용은 의무적이며 화용적인 요소이다. 즉, 한국어의 경어법은 존중, 경의를 나타내는 화용적 행 동이 반영된 것이라고 볼 수 있다(Agha, 2007). 한국어에서는 청자 의 상대적 지위에 따라 서술어의 종결어미를 변화시켜 문장 유형 을 달리하여 상대에게 공손함을 전달한다. 즉, 상대의 사회적 지위 에 대한 정보는 어떻게 의사소통할지 예측할 수 있게 해주며 화자 와 상대의 위계 관계에 따라 존칭의 형태가 달라진다. 따라서, 발화 처리과정에서 사회적 지위에 대한 정보가 미치는 영향과 한국어가 가지는 언어 특성 중 하나인 경어법 처리는 중요하게 다루어질 필 요가 있다. 그러나 한국어 경어법 처리과정에 대한 연구는 많지 않 다. 또한, 한국어 경어법 처리과정에서의 언어 표상과 처리과정의 기저를 이루는 복잡한 메커니즘을 이해하기 위해서는 신경학적 활 동에 관한 연구가 필요하다. 언어가 처리된 이후뿐만 아니라 실시 간 처리과정(real-time online processing)에 대한 연구가 필요하다.

사건관련전위(event-related potential, ERP)는 특정한 자극이 주 어졌을 때 그것에 대한 반응으로 일정한 시간 동안 나타나는 뇌의 전기적 활동을 의미한다. ERP는 시간 해상도(temporal resolution) 가 높아 인지 및 언어 처리과정을 실시간으로 기록할 수 있는 장점 이 있다. 문장에서 적절한 경어법을 사용하기 위해서는 상대적 지 위에 따른 종결어미 및 조사 등의 활용이 필요하다. 경어법 사용에 사용되는 다양한 문법적 처리과정이 어떻게 노화에 영향을 주는 지 살펴보기 위한 연구는 아직 부족한 실정이다. 또한, 오프라인 과 제는 노화에 따른 변화를 살펴보는 데 민감하지 않을 수 있다는 점 에서, ERP와 같은 실시간 처리과정을 보여주는 온라인 분석 방법 은 노화에 따른 문법 처리 손상을 보다 상세하게 살펴볼 수 있다는 장점이 있다. 언어관련 ERP 성분으로는 의미적 오류를 반영하는 N400과 통사적 오류를 반영하는 P600이 대표적이다(Luck, 2014). 한국, 중국, 일본과 같은 동아시아권 언어의 경어법 관련 ERP 연구 에서 경어법 처리과정에서 N400과 P600 성분이 관찰되었다고 보 고하고 있다(Jiang et al., 2013; Kwak, 2015; Park, Cho, \& Chung, 2015; Sakai, Long, Luo, \& Sato, 2014). Kwak (2015)은 발화 문장의 이해 과정에서 대화 상황의 격식성이 경어형식 인식에 미치는 영향 을 ERP 실험을 통해 알아보았다. 호칭어에서 드러난 청자의 상대적
지위(높음, 낮음)와 서술어 종결어미 변화를 통한 화자의 높임 대 우수준(높임, 낮춤)이 일치하지 않을 경우, 일치하는 경우에 비해 유의하게 큰 N400 성분이 관찰되었다. 잘못된 종결어미 사용은 어 휘 통합 과정에서 오류를 야기하였으며, 이로 인해 의미 위반 조건 에서 자주 관찰되는 N400이 나타난 것으로 해석할 수 있다. Park 등(2015)은 선행 문장의 대명사 주어가 선행 문장 뒤에 오는 문장 에서의 대명사 주어에 따라 문장의 동사 및 형용사에 선어말어미 '-시-'(honorific marker)를 사용하거나 사용하지 않음으로써 공손 함과 공손하지 않음을 표현하도록 문장을 구성하였다. 높은 지위 를 갖는 주어가 선행된 문장과 선행 문장 뒤에 오는 문장에서의 명 시적 주어에 따라 적절하지 않은 경어 표현이 쓰였을 경우에 N400 이 약하게 나타났으며 낮은 지위를 갖는 주어가 선행된 문장의 경우 불일치 조건에서는 P600과 left anterior negativity (LAN) - LAN 은 자극 제시 후 150-600 ms에서 나타나는 부적(negative)방향의 파형으로 언어의 통사적 처리과정(syntactic processing)을 반영하 는 ERP 성분이다(Martín-Loeches, Muñoz, Casado, Melcon, \& Fernández-Frías, 2005). 문장 구조나 단어범주 오류에서 LAN 성 분이 나타나며(Friederici \& Weissenborn, 2007; Hagoort, Wassenaar, \& Brown, 2003) 구어 작업기억(verbal working memory)과도 관련이 있다(King \& Kutas, 1995; Matzke, Mai, Nager, Rüsseler, \& Münte, 2002)—이 나타나서 이항적(bi-phasic) ERP 패턴이 관찰되 었다. 이는 문장이 맥락적으로 부적절할 때 통사 오류로 인해 나타 난 결과라고 해석할수 있다.

현재 우리나라의 65 세 이상 인구는 전체 인구의 $13.4 \%$ 를 차지하 며 2060년에는 $40 \%$ 대에 이를 것으로 추정되고 있다. 노인 인구의 증가에 따라 노년층의 건강 및 사회·경제적 문제에 대해 관심이 높 아지고 있다. 노화가 진행됨에 따라 인지·언어능력이 저하되며(Lee \& Kim, 2012) 인지·언어능력 기능의 저하는 일상생활에 영향을 미 치고 치매 등 신경학적 질환과도 연계된다(Bialystok \& Poarch, 2014). 인지·언어능력은 기억력, 주의력, 지남력, 추론력, 문제해결 력, 조직화 능력, 화용언어 등 포괄적으로 여러 영역을 다룬다. 뇌에 서 기능하는 사고 및 행동에서의 변화로 인해 노화에 따라 인지·언 어 능력이 저하되므로(Howieson, Loring, \& Hannay, 2004) 연령이 높아질수록 인지·언어적 자극을 지속시키는 것이 매우 중요하다 (Lee, 2015). 언어를 통한 의사소통은 일상생활에서 기본적인 수단 이 되며 삶의 질에 영향을 미치므로 노년층의 언어능력에 관심을 가지고 살펴볼 필요가 있다.

실시간(on-line 또는 real-time) 측정방법을 통해 연령에 따른 문 장이해능력의 감소를 보고한 연구들이 있으며(Caplan, DeDe, Waters, Michaud, \& Tripodis, 2011; Kemtes \& Kemper, 1999), 연령에 
따른 N400 성분의 진폭 감소 및 지연된 출현시각을 보고한 연구들 이 있다(Gunter, Jackson, \& Mulder, 1992; Kutas \& Iragui, 1998; Woodward, Ford, \& Hammett, 1993). 여러 연구에서 청년에 비해 노년층에서 의미적으로 적절하지 않을 경우 $\mathrm{N} 400$ 이 지연되고 진폭 이 감소되어 나타난다고 보고하고 있다(Gunter et al., 1992; Gunter, Jackson, \& Mulder, 1996; Harbin, Marsh, \& Harvey, 1984; Woodward et al., 1993).

한국어 경어법 처리에 대한 ERP 연구는 많지 않고 청년층을 대 상으로 하고 있으며 노년층을 대상으로 한 연구는 찾아보기 어렵 다. 노화로 인해 인지능력이 저하된 노년층을 대상으로 ERP 실험 이 이루어질 경우 청년층과는 다른 결과를 기대할 수 있을 것이다.

본 연구에서는 한국어가 가지는 독특한 언어형식인 경어법 처리 과정을 청년층과 노년층을 대상으로 $\mathrm{ERP}$ 실험을 통해 살펴보고자 한다. 선행하는 호칭에서 나타나는 청자의 상대적 지위와 지위에 대한 서술어 종결어미가 일치하는지에 따라 자극 제시 후 300-500 $\mathrm{ms}, 500-800 \mathrm{~ms}$ 구간의 평균진폭(mean amplitude) 및 정반응률과 반응시간을 알아보고자 한다. 경어법은 문법적 요소를 가지고 있으 면서 화용적 측면에 맞춰져 있으므로 문법적 오류로 인해 P600이, 화용 오류로 인해 $\mathrm{N} 400$ 성분이 관찰될 것으로 예상되며 청년층과 노년층의 ERP 패턴에 차이가 있을 것으로 본다.

본 연구의 구체적인 연구 질문은 다음과 같다.

첫째, 경어법 문장 처리에서 청자의 상대적 지위(높음, 낮음)와 서술어 종결어미 일치 여부에 따라 문장판단과제의 정반응률 및 반응시간에서 집단 간(노년층, 청년층) 차이가 유의한가?

둘째, 경어법 문장 처리에서 청자의 상대적 지위(높음, 낮음)와 서술어 종결어미 일치 여부에 따라 집단 간(노년층, 청년층) $\mathrm{ERP}$ 의 평균진폭(mean amplitude)의 차이가 유의한가?

\section{연구 방법}

\section{연구 대상}

청년층 23 명과 노년층 21 명, 총 44 명이 본 연구에 참여하였다. 청 년층은 만 20-40세, 노년층은 만 60-80세로 집단을 구분하였다.

두 집단은 공통적으로 (1) 한국어를 모국어로 사용하며, (2) 교육 년수가 9년 이상이며, (3) 서울, 경기, 충남 지역에 거주하며, (4) 오른 손잡이이고 시력 혹은 교정시력이 정상이며, (5) 언어 및 인지발달 에 문제가 없고 신경학적·정신적 병력이 없는 자이며, (6) GDS (Geratric Depression Scale; Jung, Kwak, Joe, \& Lee, 1997)—노인 우울 증 척도(GDS)는 우울 정도를 평가하는 척도로 대상자가 총 30 문 항에 대해 ‘예’ 또는 ‘아니오'로 응답하는 양분 척도이다. 각 문항당
Table 1. Descriptive information on participants

\begin{tabular}{lcc}
\hline & Young group ( $\mathrm{N}=23)$ & Elderly group $(\mathrm{N}=21)$ \\
\hline Gender (male:female) & $4: 19$ & $3: 18$ \\
Age (yr) & $27.26(3.89)$ & $67.10(3.78)$ \\
Education (yr) & $15.39(1.41)$ & $11.62(2.18)$ \\
K-MMSE & $29.65(0.49)$ & $28.05(2.06)$ \\
\hline
\end{tabular}

Values are presented as mean (SD).

K-MMSE = Korean version of Mini-Mental State Examination (Kang, Na, \& Hahn, 1997).

0점 또는 1점을 부여하여 점수가 높을수록 우울증상의 정도가 높 은 것을 의미한다-점수가 18 점 미만이며, (7) 한국판 간이정신상 태검사(Korean version of Mini-Mental State Examination, K-MMSE; Kang, Na, \& Hahn, 1997) 결과가 Kang (2006)에 근거하여 연령 및 교육수준에 따라 정상 범위( $16 \% \mathrm{ile})$ 이상에 속하는 대상자로 선정 하였다.

노년층은 추가적으로 서울신경심리검사 2판(Seoul Neuropsychological Screening Battery, SNSB-II; Kang, Jang, \& Na, 2012)의 2 개의 하위검사(집중력, 기억력 영역)를 실시하여, 각 하위 검사에 서의 점수가 연령 및 교육년수에 비하여 $16 \%$ ile 이상인 자로 선정하 였다. 본 연구에 참여한 집단별 대상자 정보는 Table 1 에 제시하였다.

\section{실험 자극}

본 연구에서 사용되는 실험 문장은 ‘호칭+목적어+서술어'의 3 어 절 문장으로 구성하였다. 각 문장은 호칭으로 시작되고, 서술어 종 결어미를 변화시켜 대우수준을 나타내었다.

실험 문장은 기본적으로 Kwak (2015) 연구를 기반으로 수정 및 보완하였으며 다음의 기준을 통해 선정되었다. (1) Kim (2007)을 참 고하여 상대방을 존대하는 경어법인 '하십시오체’와 상대방을 높 이지 않고 말하는 등급의 경어법인 ‘해체’를 종결어미에 사용하였 다. Kwak (2015)에서는 4 가지 종결어미 유형을 사용하였으나 본 논 문에서는 노년층 연구를 위해, 기존 연구의 종결어미 유형을 모두 사용하기 보다는 실험 문장의 수준 차이를 극대화하기 위해 극존 칭 형태와 가장 하대하는 형태의 종결어미 유형을 사용하였다. (2) 기존 연구에서는 격식성 및 일치성에 따라 실험 문장을 구성하였 으나 본 논문에서는 노화에 따른 경어법 처리 연구를 효율적으로 살펴보고자 일치 여부에 집중하여 문장을 구성하였다. (3) 직함, 사 람 이름에 호격조사를 사용하여 사회적 지위수준을 나타내었다. 높은 지위수준을 나타내기 위해서 호격조사 '님'을 붙여 '직함+님' 을 사용하였고, 낮은 지위수준을 나타내기 위해서 호격조사 ‘야’를 붙여 '이름+야'를 사용하였다. (4) 한국어의 기본적인 '주어-목적 어-서술어' 문장구조에서 문맥의 흐름상 주어가 없어도 그 문장의 
Table 2. Examples of experimental sentences

\begin{tabular}{|c|c|c|c|}
\hline Social-status (appellation) & Object & Predicate & Match condition \\
\hline \multirow[t]{2}{*}{ High $\rightarrow$ Kyoswu-nim (professor) } & cwumwun-ul (the order) & High $\rightarrow$ Chwisohayss-supnita (have canceled) & Match \\
\hline & & Low $\rightarrow$ Chwisohayss-e (have canceled) & Mismatch \\
\hline \multirow[t]{2}{*}{ Low $\rightarrow$ Mimswu-ya } & & Low $\rightarrow$ Chwisohayss-e (have canceled) & Match \\
\hline & & High $\rightarrow$ Chwisohayss-supnita (have canceled) & Mismatch \\
\hline
\end{tabular}

주어가 무엇인지를 알 수 있을 때 주어를 생략하여 사용하며, (5) 화 자와 청자의 관계가 연관되는 상대경어에서, 화자와 청자의 관계를 명확하게 해주는 단서가 되는 주어를 생략하여 '호칭+목적어+서 술어' 구조의 3 어절 문장을 사용하였다.

호칭에서 나타나는 높고, 낮은 지위수준에 대해 각각 서술어 종 결어미 일치 여부에 따라 2 가지 문장이 구성이 되며, 총 4 가지 실험 조건으로 구성되었다(높은 상대적 지위와 종결어미 일치 문장, 높 은 상대적 지위와 종결어미 불일치 문장, 낮은 상대적 지위와 종결 어미 일치 문장, 낮은 상대적 지위와 종결어미 불일치 문장). 문장 자극은 위의 4 개의 조건에서 각 조건당 20 개의 문장이 만들어졌으 며, 60 개의 채움 문장(filler sentence)을 추가하여 총 140 개 문항으 로 구성하였다. 채움 문장은 조건 문장과 문법적으로 동일한 구조 를 가지는 문장으로 제작되었다. 이에 따른 실험 문장의 예시는 Table 2에 제시하였으며, 실험 문장 목록은 Appendix 1에 제시하였 다. 실험 문장의 예시는 Yale Romanization 체계(Martin, 1992)에 따라 표기하였다.

\section{연구 절차}

문장판단과제(sentence plausibility task)

실험자극은 총 140 개 문항으로 유사무작위배열(pseudo-randomization)하여 4 개의 리스트를 만들고 연구 대상자가 오는 순서대 로 돌아가며 사용하였다. 각각의 리스트별로 35문항씩 4세트로 구 성하여 실험을 실시하였으며, 한 세트가 끝난 후 약 1 분간 휴식하였 다. '‘' 표시가 화면 가운데에 나타나 피험자의 시선을 고정시키고 3 어절 문장이 한 어절씩 나뉘어져 나타났다 사라진 뒤, 3 어절이 합쳐 진 전체 문장을 다시 한번 제시하였다. 본 실험을 시작하기 전에 연 습문항을 실시하여, 피험자에게 전체 문장이 제시되었을 때 적절 한 형식의 단어형태가 쓰였는지, 문장의 내용이 이치에 맞는지에 따라 문법적, 의미적으로 '문장이 말이 된다' 라고 생각하면 키보드 오른쪽에 표시된 파란색 버튼을, '문장이 말이 안 된다' 라고 생각 하면 왼쪽에 표시된 빨간색 버튼을 누르도록 하였다. 연습문항을 통해 대상자가 과제수행 방법을 익혀 본 실험 시 과제를 수행하는 데 어려움이 없도록 하였다. 연습문항은 본 실험의 조건문장 4 개와
채움 문장(filler sentences) 2개를 포함하였으며, 연습문항에서만 대상자의 반응에 대해 피드백을 제공하였다.

시선을 고정하기 위해 ‘'’ 표시가 나타나는 시간은 $500 \mathrm{~ms}$ 이며, 한 어절씩 제시할 때의 1 어절 제시 시간은 $700 \mathrm{~ms}$ 로 하였다. 시선 고정 화면과 어절 제시 화면 사이마다 $200 \mathrm{~ms}$ 의 빈 화면을 두었다. 어절 제시 후 전체 문장을 최대 $4,000 \mathrm{~ms}$ 동안 제시하였으며, 피험 자가 버튼을 눌러 반응을 하면 해당 문장은 바로 사라지도록 하였 다. $4,000 \mathrm{~ms}$ 가 지나도 추가적으로 $3,000 \mathrm{~ms}$ 의 눈 깜빡임 시간을 두었다. 실험의 소요시간은 약 20 분이며, 중간에 3 번의 휴식시간을 포함하면 약 30-40분이 소요되었다. 문장판단과제의 자극 제시 순 서는 Figure 1에 제시하였다.

\section{$\mathrm{ERP}$ 실험}

Brain Products사의 32채널 BrainAmp Standard와 actiCAP으 로 뇌전도(EEG)를 측정하였으며 측정 절차는 다음과 같다. 먼저 전파를 차단하도록 제작된 쉴드룸(shield room) 안에 대상자를 착 석시킨 뒤 대상자의 두피에 전극을 부착하였다. 적극은 은/염화은 (Ag/AgCI)으로 제작되었으며, 국제 표준방식인 10-20 system (Jasper, 1958)에 따라 Fp1, Fp2, F7, F3, Fz, F4, F8, FC5, FC1, FC2, FC6, T7, C3, C2, C4, T8, TP9, CP5, CP1, CP2, CP6, TP10, P7, P3, Pz, P4, $\mathrm{P} 8, \mathrm{O} 1, \mathrm{O} 2$ 의 총 29 개 부위에 부착하였다. 분석에 포함된 전극은 midline (Fz, Cz, Pz), left anterior (FP1, F3, FC5, FC1, F7), left posterior (CP5, CP1, P7, P3, O1), right anterior (FP2, F4, FC2, FC6, $\mathrm{F} 8)$, right posterior (CP2, $\mathrm{CP} 6, \mathrm{P} 4, \mathrm{P} 8, \mathrm{O} 2)$ 이다. 눈 깜빡임을 탐지 하기 위해 오른쪽 눈 밑 약 10-15 mm에 전극을 부착하여 안구 전 위도(electrooculogram, EOG)를 측정하였다. 추가적인 기준전극 (reference electrodes)은 피험자의 좌우 유양돌기(mastoids)에 부착 하였다. 뇌파 신호는 $500 \mathrm{~Hz}$ 의 샘플링 레이트(sampling rate)로 기 록되었고, 전극저항은 $10 \mathrm{k} \Omega$ 이하로 유지되었다. 피험자에게 실험 과정과 주어지는 과제에 대해 간략하게 설명을 하고 $1 \mathrm{~m}$ 앞에 있는 모니터의 중앙에 시선을 집중하도록 하였다. 문장이 제시되는 동안 눈을 깜빡이거나 몸을 움직이지 말 것을 주의시킨 뒤, 쉴드룸의 전 등을 끄고 문을 닫은 상태에서 실험을 진행하였다. 실험이 진행되 


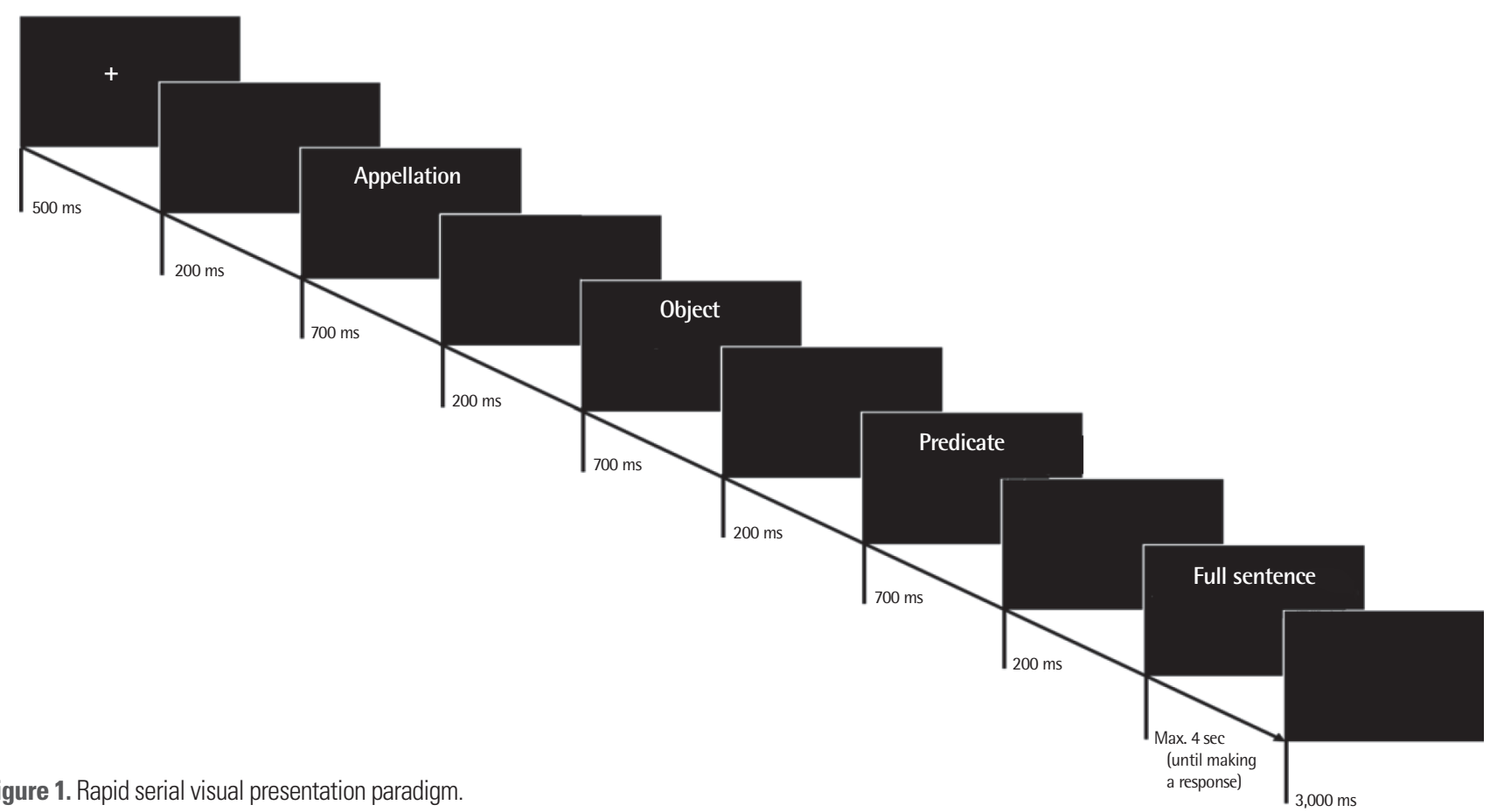

Figure 1. Rapid serial visual presentation paradigm.

는 모든 과정에서 EEG가 기록되었으며, 제시된 실험 문장의 마지 막 단어인 동사가 실험단어(critical word)로 기록되었다.

\section{자료 분석}

\section{문장판단과제}

문장판단과제의 정반응률은 피험자가 '문장이 말이 되는지' 혹 은 '문장이 말이 되지 않는지'를 버튼을 눌러 판단한 반응을 분석 하였다. 청자의 상대적 지위 및 서술어 종결어미 유형 조건별로 정 반응한 목표 문장 수를 전체 목표 문장 수로 나누어 백분율(\%)로 계산하였다.

반응시간은 밀리세컨드 $(\mathrm{ms})$ 단위로 측정하였으며 피험자가 정 반응한 문항에 대해서만 반응시간을 분석하였다. 반응시간의 표준 편차(SD)를 구하여 $\pm 3 \mathrm{SD}$ 범위를 벗어나는 값은 이상값(outlier) 으로 처리하여 분석에서 제외하였다

본 연구의 첫 번째 연구 문제인 집단 간 청자의 상대적 지위와 서 술어 종결어미 일치 여부에 따라 문장판단과제의 정반응률 및 반응 시간의 차이가 유의한지를 알아보기 위해 삼원혼합분산분석(threeway mixed ANOVA)를 실시하였다

\section{$\mathrm{ERP}$ 실험}

문장판단과제를 수행하는 동안 기록된 피험자의 EEG 데이터를 MATLAB R2013b와 EEG LAB v12.0.2.5b 프로그램을 이용하여
분석하였다. 피험자들이 문장판단과제에서 정반응한 시행들만을 선택한 후, $250 \mathrm{~Hz}$ 로 다시 샘플링(resampling) 한 뒤, 실험단어(문 장의 마지막 어절)가 제시되기 전 $200 \mathrm{~ms}$ 부터 실험단어가 제시되 기까지의 $200 \mathrm{~ms}$ 구간의 값을 기저선(baseline)으로 하여 실험단어 가 제시된 시점부터 자극이 제시된 후 $900 \mathrm{~ms}$ 까지 총 $1,100 \mathrm{~ms}$ 구간 (epoch)을 잘랐다. 인지작용과 관련된 뇌파 범위인 $0.1-30 \mathrm{~Hz}$ 로 대 역 여과(band-pass filter) 하였다. 눈 깜박임을 보정하기 위하여 안 구 교정(ocular correction)을 한 뒤 기타 잡음(artifacts)들을 없애 기 위해 $\pm 50 \mu \mathrm{V}$ 를 넘는 시행(trial)들은 제거하였다. 이러한 과정 을 거친 후 남은 시행들을 청자의 상대적 지위 및 서술어 종결어미 유형 조건별로 추출하고 평균을 내어 각 집단의 평균 ERP 파형을 구하였다.

실험에 참여한 44 명(청년층 23 명, 노년층 21 명) 중 문장판단과제 의 정확도 및 반응시간에서 이상값(outlier)으로 제외된 노년층 1 명 을 제외하고, $\mathrm{ERP}$ 데이터의 전처리 과정에서 제외된 청년층 3명을 제외한 총 40 명(청년층 20 명, 노년층 20 명)의 자료가 최종 $\mathrm{ERP}$ 데이 터 분석에사용되었다.

본 연구의 두 번째 연구 문제인 집단 간 청자의 상대적 지위와 서 술어 종결어미 일치 여부에 따라 ERP의 평균진폭(mean amplitude) 의 차이가 유의한지를 알아보기 위해 midline 영역에서는 사원혼 합분산분석(four-way mixed ANOVA)을 실시하였으며, 좌우측영 역 및 전두-후두영역에서는 오원혼합분산분석(five-way mixed 
ANOVA)을 실시하였다.

\section{연구 결과}

\section{청자의 상대적 지위 및 서술어 종결어미 일치 여부에 따른}

\section{문장판단과제 행동분석}

정반응률

청자의 상대적 지위와 서술어 종결어미 일치성에 따른 집단별 정 반응률은 Figure 2에 제시하였다. 청년층의 평균 정반응률(98.81\%) 이 노년층의 평균 정반응률(82.38\%)보다 유의하게 높은 것으로 나 타났다. 상대적 지위에 대한주효과도 통계적으로 유의하였다 $\left(F_{(1,38)}=\right.$ $27.062, p<.001)$. 즉, 높은 상대적 지위에서의 정반응률 $(94.25 \%)$ 이 낮은 상대적 지위에서의 정반응률(86.94\%)보다 유의하게 높은 것 으로 나타났다. 또한, 종결어미 일치성에 대한 주효과도 통계적으 로 유의하였다 $\left(F_{(1,38)}=3106.406, p<.001\right)$. 즉, 일치 조건에서의 정 반응률(95\%)이 불일치 조건에서의 정반응률(88.19\%)보다 유의하 게 높은 것으로 나타났다.

집단과 상대적 지위 간의 이차상호작용이 통계적으로 유의하였 다 $\left(F_{(1,38)}=22.634, p<.001\right)$. 즉, 정상 청년의 경우와 비교하여 정상 노년의 경우 높은 상대적 지위에 비해 낮은 상대적 지위에서 더 큰 수행의 지체를 보였다. 집단과 일치성 간의 이차상호작용도 통계적 으로 유의하였다 $\left(F_{(1,38)}=15.792, p<.001\right)$. 즉, 정상 청년층과 비교 하여 정상 노년층의 경우 일치 조건에 비해 불일치 조건에서 더 큰 수행의 지체를 보였다.

상대적 지위와 일치성 간의 이차상호작용도 통계적으로 유의하 였다 $\left(F_{(1,38)}=7.179, p<.05\right)$. 즉, 높은 상대적 지위와 비교하여 낮은 상대적 지위에서 일치 조건에 비해 불일치 조건에서 더 큰 수행의 지체를 보였다. 마지막으로, 집단 및 상대적 지위, 종결어미 일치성

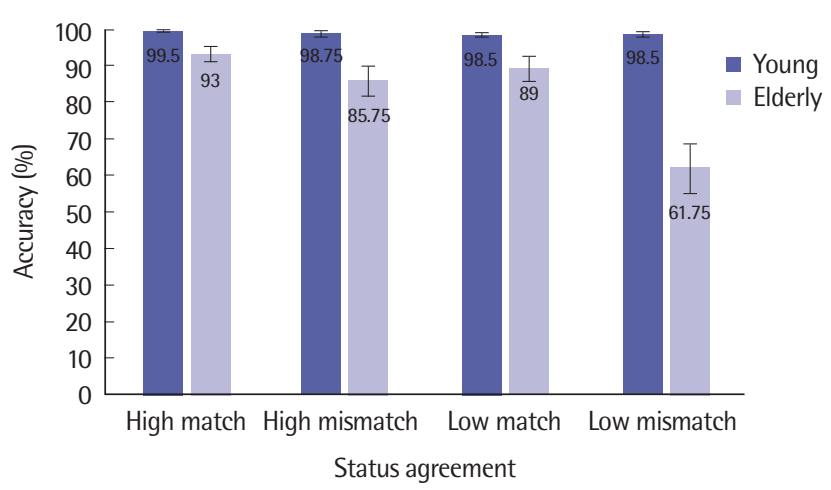

Figure 2. Accuracy of sentence plausibility task for each condition in young and elderly groups.
간 삼차상호작용도 통계적으로 유의하였다 $\left(F_{(1,38)}=8.342, p<.01\right)$. 즉, 노년층에서는 낮은 상대적 지위에서 종결어미 일치성 간 정반 응률의 차이가 높은 상대적 지위에서 종결어미 일치성 간 정반응 률의차이에 비해 큰 것으로 나타났다.

반응시간

청자의 상대적 지위와 서술어 종결어미 일치성에 따른 집단별 반 응시간은 Figure 3에 제시하였다. 청자의 상대적 지위 및 서술어 종 결어미 일치성에 따른 문장판단과제의 반응시간에서 집단에 대한 주효과가 통계적으로 유의하였다 $\left(F_{(1,38)}=60.584, p<.001\right)$. 즉, 청년 층의 반응시간 $(333.84 \mathrm{~ms})$ 이 노년층의 반응시간 $(1,465.81 \mathrm{~ms})$ 에 비 해 유의하게 빨랐다. 상대적 지위에 대한 주효과도 통계적으로 유 의하였다 $\left(F_{(1,38)}=17.849, p<.001\right)$. 즉, 높은 상대적 지위에서의 반응 시간 $(852.05 \mathrm{~ms})$ 이 낮은 상대적 지위에서의 반응시간 $(947.59 \mathrm{~ms})$ 에 비해 유의하게 빨랐다. 종결어미 일치성에 대한 주효과도 통계적으 로 유의였다 $\left(F_{(1,38)}=4.358, p<.05\right)$. 즉, 일치 조건에서 반응시간 $(867.50 \mathrm{~ms})$ 이 불일치 조건에서 반응시간 $(932.14 \mathrm{~ms})$ 에 비해 유의 하게 빨랐다.

집단과 상대적 지위 간의 이차상호작용이 통계적으로 유의하였 다 $\left(F_{(1,38)}=13.412, p<.01\right)$. 즉, 정상 청년의 경우와 비교하여 정상 노 년의 경우 낮은 상대적 지위에 비해 높은 상대적 지위에서의 반응 시간이 더 빨랐다.

\section{청자의 상대적 지위 및 서술어 종결어미 일치 여부에 따른 ERP 성분의 평균진폭(mean amplitude) 크기 분석}

청년층과 노년층의 ERP 분석에 따른 평균 파형(grand average waveforms) 결과는 Figures 4-7에 제시하였으며 각 구간 별 영역에 대한 분산분석 결과는 Table 3,4 에 제시하였다.

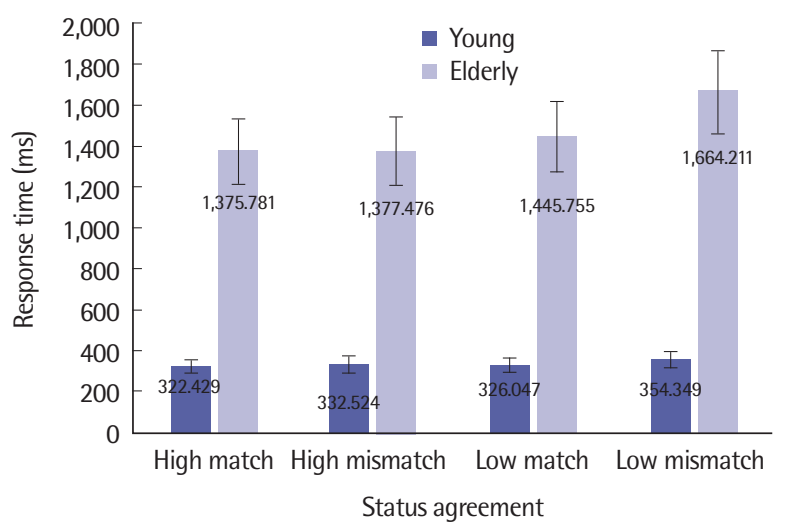

Figure 3. Response time of sentence plausibility task for each condition in young and elderly groups. 


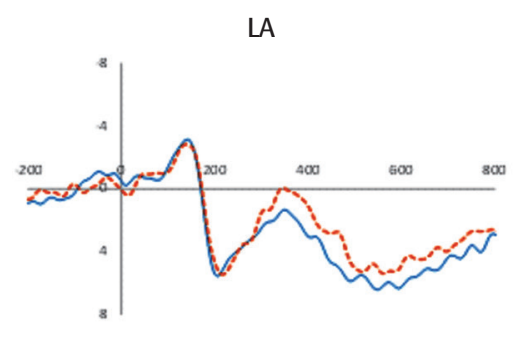

LP

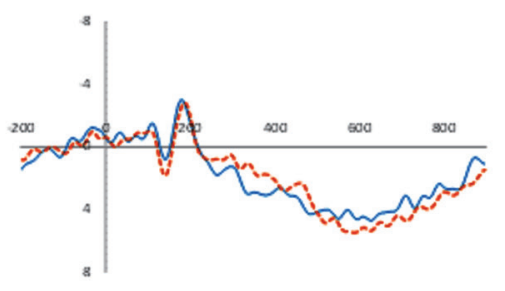

$\mathrm{Fz}$

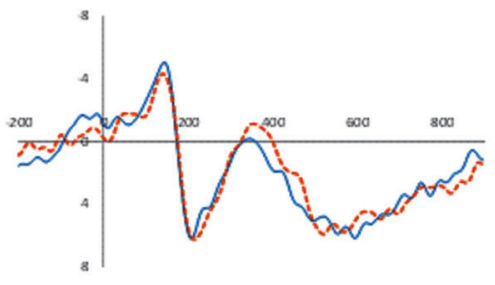

$\mathrm{Cz}$

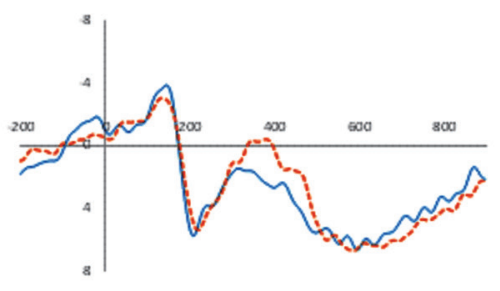

$\mathrm{Cz}$

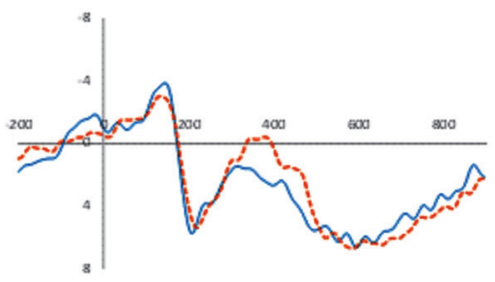

RA

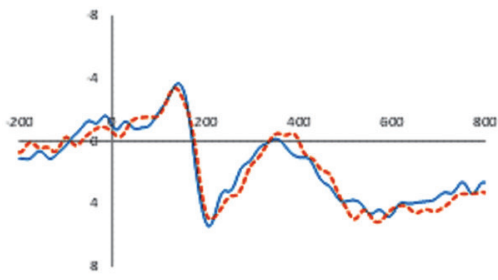

RP

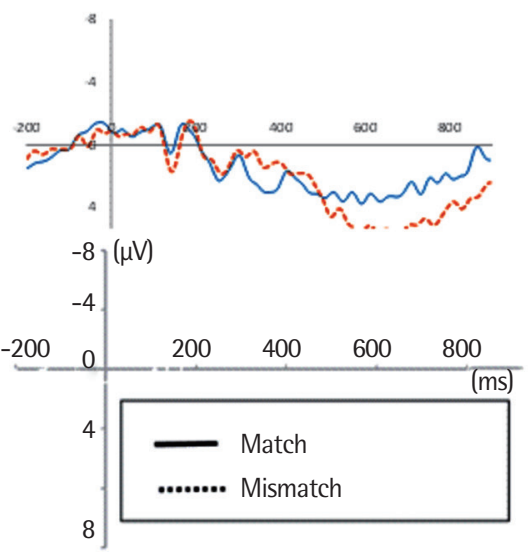

Figure 4. Grand-average waveforms for critical word of higher status for young adults. $L A=$ left anterior; $L P=l$ eft posterior; $R A=$ right anterior; $R P=$ right posterior.

\section{동사 제시 후 300-500 ms 구간}

Midline 영역 분석

Midline 영역에서의 청자의 상대적 지위 및 서술어 종결어미 일 치성에 따른 경어법 문장에 대한 문장판단과제의 300-500 ms 구간 의 평균진폭에서 midline에 대한 주효과가 통계적으로 유의하였 다 $\left(F_{(1.364,51.842)}=6.967, p<.01\right)$. 즉, midline에 따라 300-500 ms 구간 의 평균진폭의 차이가 유의한 것으로 나타났다. 이에 따라 Bonferroni 사후검정을 통하여 주효과에 대한 대응별 비교를 실시한 결 과, $\mathrm{Cz}$ 에서의 평균진폭크기 $(1.273 \mu \mathrm{V})$ 가 $\mathrm{Fz}$ 에서의 평균진폭크기 $(.435 \mu \mathrm{V})$ 보다 유의하게 큰 것으로 나타났으며 $(p<.05), \mathrm{Pz}$ 에서의 평균진폭크기 $(1.675 \mu \mathrm{V})$ 가 $\mathrm{Fz}$ 에서의 평균진폭크기 $(.435 \mu \mathrm{V})$ 보다 유의하게 큰 것으로 나타났다 $(p<.05)$. 또한, midline 영역 및 상대 적 지위, 일치성 간 삼차상호작용도 통계적으로 유의하였다 $\left(F_{(1,53)}=\right.$ $3.618, p<.05)$. 즉, midline 영역 및 상대적 지위에 따른 일치성 간 평균진폭 크기의 차이가 유의하였다. LMATRIX와 MMATRIX 명 령문을 사용하여 사후검정을 실시한 결과, $\mathrm{Fz}, \mathrm{Cz}, \mathrm{Pz}$ 간 평균진폭 크기의 차이가 유의하지 않은 것으로 나타났다 $(p>.05)$. 그 외 주효
과 및 상호작용은 유의하지 않았다.

\section{좌우측영역 및 전두-후두영역 분석}

좌우측영역 및 전두-후두영역에서의 청자의 상대적 지위 및 서 술어 종결어미 일치성에 따른 경어법 문장에 대한 문장판단과제의 300-500 ms 구간의 평균진폭에서 집단에 대한 주효과가 통계적으 로 유의하였다 $\left(F_{(1,38)}=6.788, p<.05\right)$. 즉, $300-500 \mathrm{~ms}$ 구간에서 청 년층의 평균진폭 $(2.056 \mu \mathrm{V})$ 이 노년층의 평균진폭 $(.259 \mu \mathrm{V})$ 에 비해 유의하게 큰 것으로 나타났다. 또한, 좌우측영역에 대한 주효과도 통계적으로 유의하였다 $\left(F_{(1,38)}=46.125, p<.001\right)$. 즉, $300-500 \mathrm{~ms}$ 구 간에서 좌측영역의 평균진폭 $(1.927 \mu \mathrm{V})$ 우측영역의 평균진폭(.388 $\mu \mathrm{V})$ 에 비해 유의하게 더 큰 것으로 나타났다.

집단과 좌우측영역 간 이차상호작용이 통계적으로 유의하였다 $\left(F_{(1,38)}=6.023, p<.05\right)$. 노년층에서의 좌우측영역 간 평균진폭의 차 이가 청년층에서의 좌우측영역 간 평균진폭의 차이보다 유의하게 큰 것으로 나타났다. 좌우측영역과 전두-후두영역 간 이차상호작 용도 통계적으로 유의하였다 $\left(F_{(1,38)}=30.546, p<.001\right)$. 또한, 집단 
LA

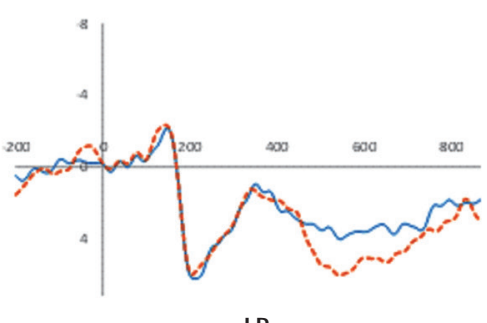

LP

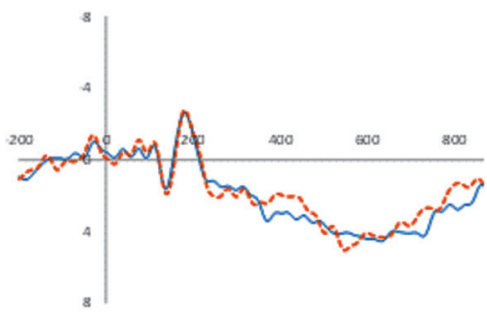

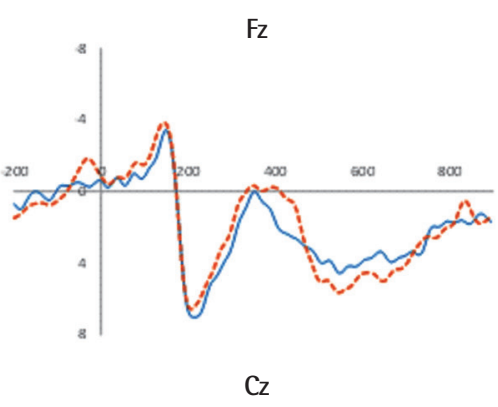

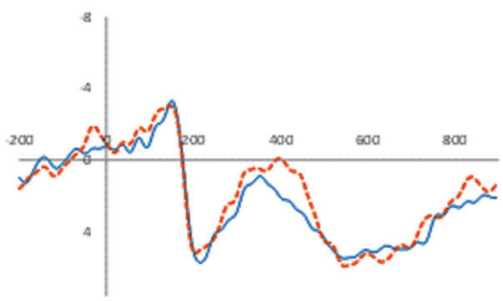

$\mathrm{Pz}$

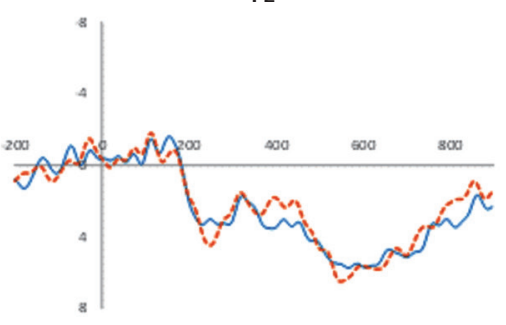

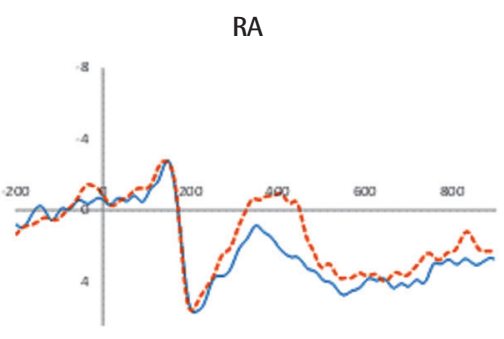

RP

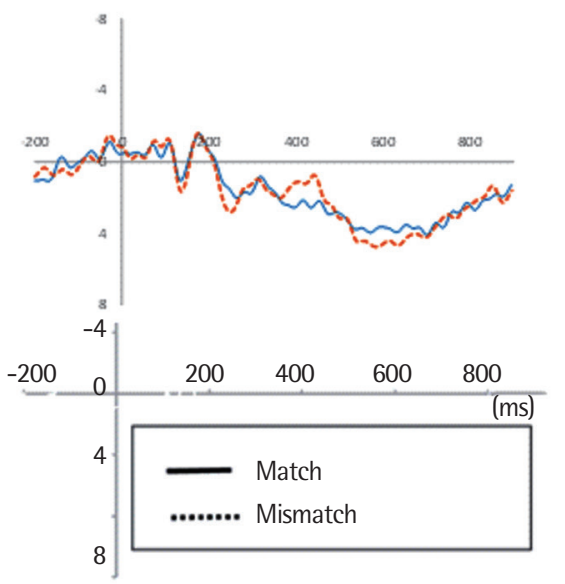

Figure 5. Grand-average waveforms for critical word of lower status for young adults. $L A=$ left anterior; $L P=$ left posterior; $R A=$ right anterior; $R P=$ right posterior.

및 좌우측영역, 전두-후두영역 간 삼차상호작용이 통계적으로 유 의하였다 $\left(F_{(1,38)}=12.994, p<.01\right)$. LMATRIX와 MMATRIX 명령 문을 사용하여 집단, 좌우측영역, 전두-후두영역 간 삼차상호작용 에 대한 사후검정을 실시한 결과, 각 집단에서 좌우측영역에 따른 전두-후두영역 간 평균진폭크기의 차이가유의하지 않았다 $(p>.05)$. 상대적 지위, 일치성, 좌우측영역 간 삼차상호작용도 통계적으로 유의하였다 $\left(F_{(1,38)}=31.02, p<.001\right)$. 즉, 좌측 영역에서 상대적 지위 에 따른 종결어미 일치성 간 평균진폭의 차이가 우측영역에서 상대 적 지위에 따른 종결어미 일치성 간 평균진폭의 차이에 비해 유의 하게 컸다. MMATRIX를 사용하여 사후검정을 실시한 결과, 좌우 측영역에서 상대적 지위에 따른 일치성 간 평균진폭 크기의 차이가 유의하지 않았다( $p>.05)$. 상대적 지위, 일치성, 전두-후두영역 간 삼차상호작용도 통계적으로 유의하였다 $\left(F_{(1,38)}=4.452, p<.05\right)$. MMATRIX를 사용하여 사후검정을 실시한 결과, 전두-후두영역 에서 상대적 지위에 따른 일치성 간 평균진폭 크기의 차이가 유의 하지 않았다 $(p>.05)$. 또한, 집단 및 일치성, 좌우측영역, 전두-후두 영역 간 사차상호작용이 통계적으로 유의하였다 $\left(F_{(1,38)}=6.137\right.$, $p<.05)$. LMATRIX와 MMATRIX 명령문을 사용하여 집단, 일치
성, 좌우측영역, 전두-후두영역 간 사차상호작용에 대한 사후검정 을 실시한 결과, 좌측 전두-후두영역에서 집단에 따른 일치성 간 차 이가 유의하였으며 $(p<.01)$ 우측 전두영역에서 집단에 따른 일치성 간 차이도 유의하였다 $(p<.001)$. 우측 후두영역에서 집단에 따른 일치성 간 차이도 유의하였다 $(p<.05)$. 마지막으로 상대적 지위, 일 치성, 좌우측영역, 전두-후두영역 간 사차상호작용도 통계적으로 유의하였다 $\left(F_{(1,38)}=37.203, p<.001\right)$. MMATRIX 명령문을 사용하 여 상대적 지위, 일치성, 좌우측영역, 전두-후두영역 간 사차상호작 용에 대한 사후검정을 실시한 결과, 우측 후두영역에서 상대적 지 위에 따른 일치성 간 차이가 유의하지 않은 반면, 좌측 전두-후두영 역과 우측 전두영역에서 상대적 지위에 따른 일치성 간 차이가 유 의하였다 $(p<.01)$.

\section{동사 제시 후 500-800 ms 구간}

Midline 영역분석

집단에 대한 주효과가 통계적으로 유의하였다 $\left(F_{(1,38)}=30.957\right.$, $p<.001)$. 즉, $500-800 \mathrm{~ms}$ 구간에서 청년층의 평균진폭 $(4.806 \mu \mathrm{V})$ 이 노년층의 평균진폭(. $105 \mu \mathrm{V})$ 에 비해 유의하게 더 큰 것으로 나타 
LA

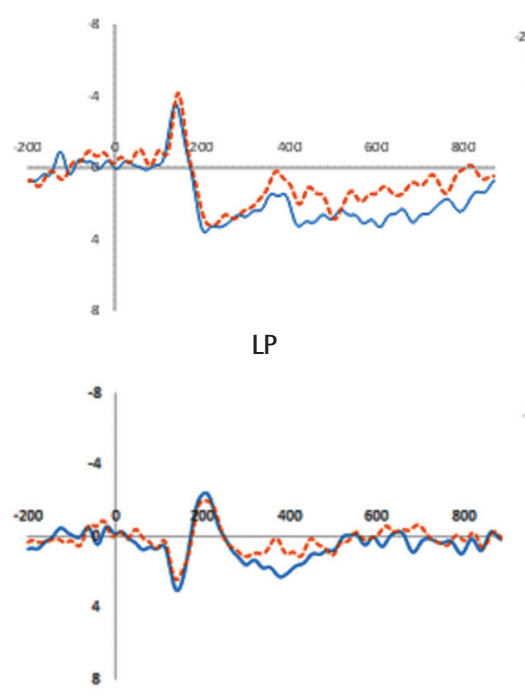

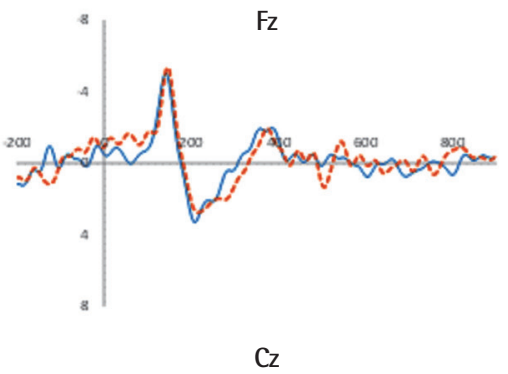

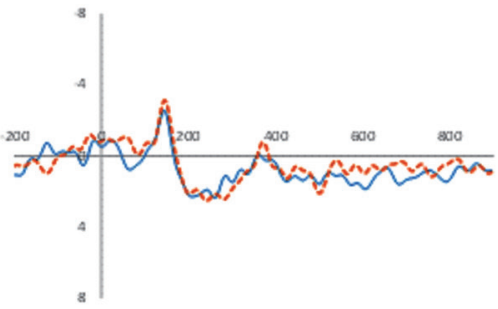

$\mathrm{Pz}$

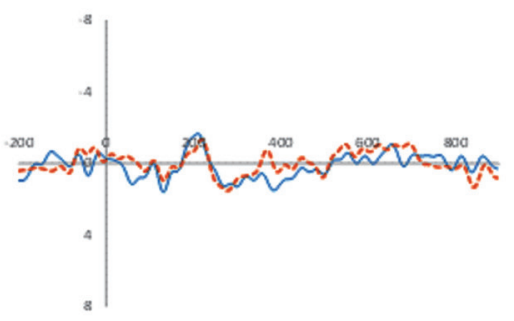

RA

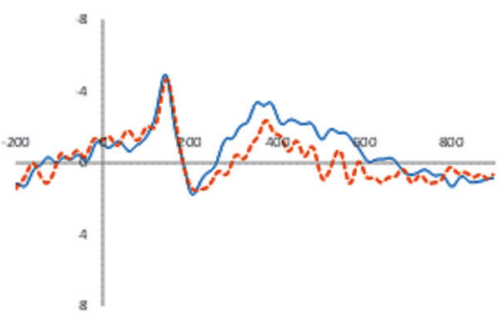

RP
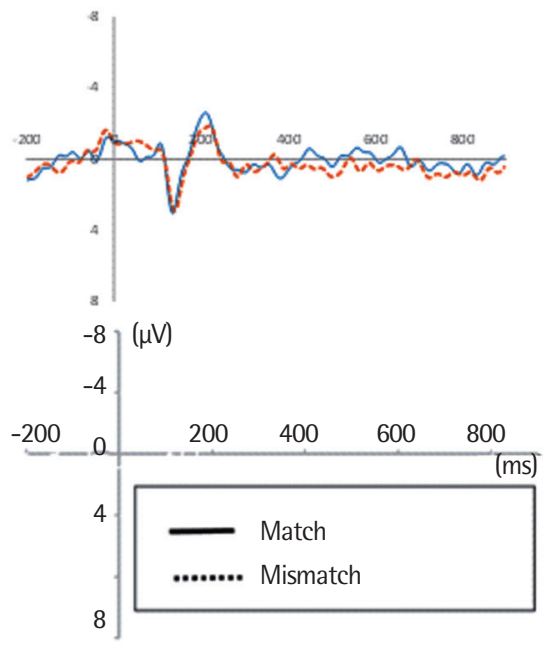

Figure 6. Grand-average waveforms for critical word of higher status for elderly adults. $L A=$ left anterior; $L P=$ left posterior; $R A=$ right anterior; $R P=$ right posterior.

났다. 또한, midline 영역 및 상대적 지위, 일치성 간 삼차상호작용 이 통계적으로 유의하였다 $\left(F_{(1.543,58.653)}=5.014, p<.05\right)$. 즉, midline 영역 및 상대적 지위에 따른 일치성 간 평균진폭 크기의 차이가 유 의하였다. LMATRIX와 MMATRIX 명령문을 사용하여 사후검정 을 실시한 결과, $\mathrm{Fz}, \mathrm{Cz}, \mathrm{Pz}$ 간 평균진폭 크기의 차이가 유의하지 않 은 것으로 나타났다( $p>.05)$.

\section{좌우측영역 및 전두-후두영역분석}

집단에 대한 주효과가 통계적으로 유의하였다 $\left(F_{(1,38)}=30.626\right.$, $p<.001)$. 즉, $500-800 \mathrm{~ms}$ 구간에서 청년층의 평균진폭 $(3.997 \mu \mathrm{V})$ 이 노년층의 평균진폭 $(.399 \mu \mathrm{V})$ 에 비해 유의하게 큰 것으로 나타났 다. 또한, 좌우측영역에 대한주효과도 통계적으로 유의하였다 $\left(F_{(1,38)}=\right.$ $6.689, p<.05)$. 즉, $500-800 \mathrm{~ms}$ 구간에서 좌측영역의 평균진폭(2.472 $\mu \mathrm{V})$ 우측영역의 평균진폭 $(1.925 \mu \mathrm{V})$ 에 비해 유의하게 더 큰 것으로 나타났다.

좌우측영역과 전두-후두영역 간 이차상호작용이 통계적으로 유 의하였다 $\left(F_{(1,38)}=17.941, p<.001\right)$. 즉, 우측영역에서의 전두-후두영
역 간 평균진폭의 차이에 비해 좌측영역에서의 전두-후두영역 간 평균진폭의 크기가 유의하게 큰 것으로 나타났다. 또한, 집단 및 좌 우측영역, 전두-후두영역 간 삼차상호작용이 통계적으로 유의하였 다 $\left(F_{(1,38)}=8.633, p<.01\right)$. LMATRIX와 MMATRIX 명령문을 사용 하여 집단, 좌우측영역, 전두-후두영역 간 삼차상호작용에 대한 사 후검정을 실시한 결과, 각 집단에서 좌우측영역에 따른 전두-후두 영역 간 평균진폭 크기의 차이가 유의하지 않았다 $(p>.05)$. 일치성, 좌우측영역, 전두-후두영역 간 삼차상호작용도 통계적으로 유의 하였다 $\left(F_{(1,38)}=30.887, p<.001\right)$. 즉, 불일치 조건에서 좌우측영역에 따른 전두 후두영역 간 평균진폭의 차이가 일치 조건에서 좌우측 영역에 따른 전두-후두영역 간 평균진폭의 차이보다 유의하게 큰 것으로 나타났다. MMATRIX를 사용하여 사후검정을 실시한 결 과, 각 일치성 조건에서 좌우측영역에 따른 전두-후두영역 간 평균 진폭 크기의 차이가 유의하지 않았다 $(p>.05)$. 상대적 지위, 일치성, 좌우측영역 간 삼차상호작용도 통계적으로 유의하였다 $\left(F_{(1,38)}=\right.$ $44.154, p<.001)$. MMATRIX를 사용하여 사후검정을 실시한 결 과, 좌측영역에서는 상대적 지위에 따른 일치성 간 평균진폭 크기 
$\mathrm{Fz}$
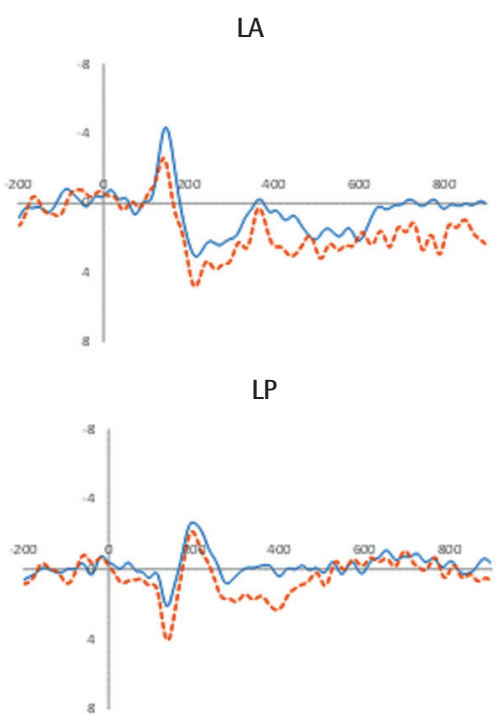
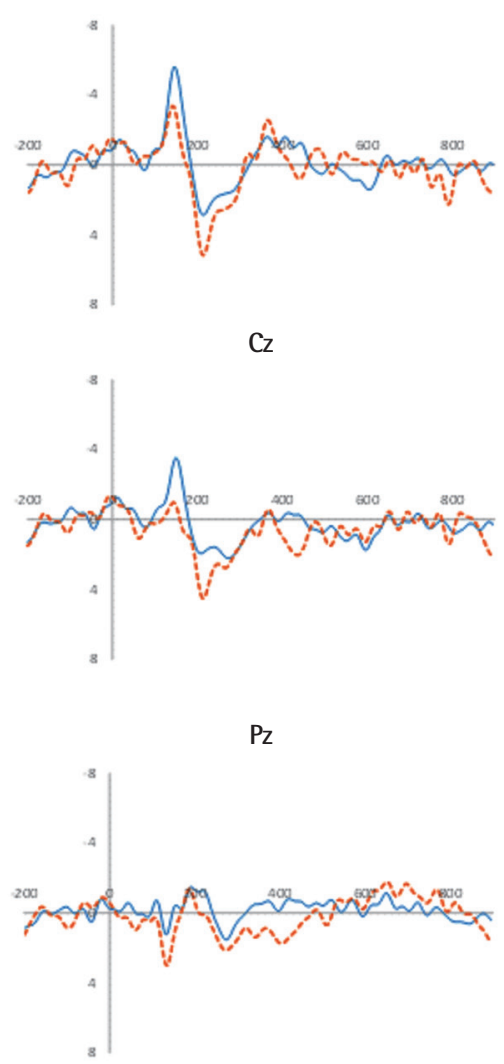

RA

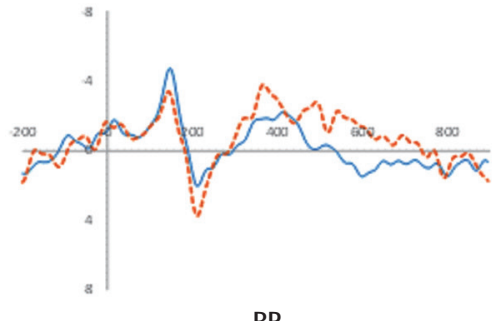

$\mathrm{RP}$
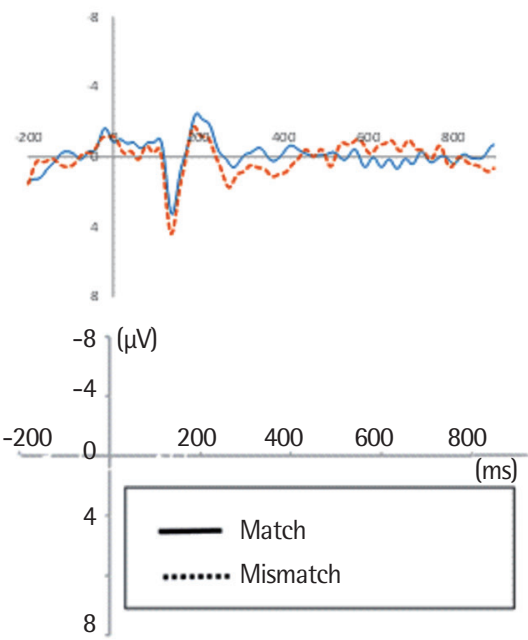

Figure 7. Grand-average waveforms for critical word of lower status for elderly adults. $L A=$ left anterior; $L P=$ left posterior; $R A=$ right anterior; $R P=$ right posterior.

Table 3. Results of ANOVAs for mean amplitude in each time window for midline

\begin{tabular}{lcc}
\hline & \multicolumn{2}{c}{ F-value } \\
\cline { 2 - 3 } Effect & $300-500 \mathrm{~ms}$ & $500-800 \mathrm{~ms}$ \\
\hline $\mathrm{S}$ & .499 & 1.868 \\
$\mathrm{~S} \times \mathrm{G}$ & .001 & .919 \\
$\mathrm{~A}$ & 1.339 & .191 \\
$\mathrm{~A} \times \mathrm{G}$ & 4.009 & .900 \\
$\mathrm{M}$ & $6.967^{* *}$ & 2.386 \\
$\mathrm{M} \times \mathrm{G}$ & 2.085 & 3.304 \\
$\mathrm{~S} \times \mathrm{A}$ & .874 & .176 \\
$\mathrm{~S} \times \mathrm{A} \times \mathrm{G}$ & .076 & .170 \\
$\mathrm{~S} \times \mathrm{M}$ & 1.169 & 1.772 \\
$\mathrm{~S} \times \mathrm{M} \times \mathrm{G}$ & .016 & .339 \\
$\mathrm{~A} \times \mathrm{M}$ & .791 & .399 \\
$\mathrm{~A} \times \mathrm{M} \times \mathrm{G}$ & .763 & 1.166 \\
$\mathrm{~S} \times \mathrm{A} \times \mathrm{M}$ & $3.618^{*}$ & $5.014^{*}$ \\
$\mathrm{~S} \times \mathrm{A} \times \mathrm{M} \times \mathrm{G}$ & 1.568 & 2.477 \\
\hline
\end{tabular}

$\mathrm{S}=$ status; $\mathrm{G}=$ group; $\mathrm{A}=$ agreement; $\mathrm{M}=$ midline . ${ }^{*} p<.05,{ }^{* *} p<.01$.
의 차이가 유의하지 않은 반면, 우측영역에서는 상대적 지위에 따 른 일치성 간 평균진폭 크기의 차이가 유의하였다 $(p<0.1)$. 상대적 지위, 일치성, 전두-후두영역 간 삼차상호작용도 통계적으로 유의 하였다 $\left(F_{(1,38)}=6.506, p<.05\right)$. MMATRIX를 사용하여 사후검정 을 실시한 결과, 전두영역에서는 상대적 지위에 따른 일치성 간 평 균진폭 크기의 차이가 유의하지 않은 반면, 후두영역에서는 상대적 지위에 따른 일치성 간 평균진폭 크기의 차이가 유의하였다 $(p<0.1)$. 또한, 집단 및 일치성, 좌우측영역, 전두-후두영역 간 사차상호작용 이 통계적으로 유의하였다 $\left(F_{(1,38)}=12.167, p<.01\right)$. LMATRIX와 MMATRIX 명령문을 사용하여 집단, 일치성, 좌우측영역, 전두후두영역 간 사차상호작용에 대한 사후검정을 실시한 결과, 좌측 과 우측 후두영역에서 집단에 따른 일치성 간 차이가 유의하지 않 은 반면, 좌측과 우측 전두영역에서 집단에 따른 일치성 간 차이가 유의하였다 $(p<.01)$. 마지막으로 상대적 지위, 일치성, 좌우측영역, 전두-후두영역 간 사차상호작용도 통계적으로 유의하였다 $\left(F_{(1,38)}=\right.$ $37.454, p<.001)$. MMATRIX 명령문을 사용하여 상대적 지위, 일 치성, 좌우측영역, 전두-후두영역 간 사차상호작용에 대한 사후검 
Table 4. Results of ANOVAs for mean amplitude in each time window for anteriority and laterality

\begin{tabular}{|c|c|c|}
\hline \multirow{2}{*}{ Effect } & \multicolumn{2}{|c|}{$F$-value } \\
\hline & $300-500 \mathrm{~ms}$ & $500-800 \mathrm{~ms}$ \\
\hline S & .508 & 1.942 \\
\hline$S \times G$ & .190 & .069 \\
\hline A & .821 & .525 \\
\hline$A \times G$ & 3.629 & .526 \\
\hline L & $46.125^{* * *}$ & $6.689^{*}$ \\
\hline$L \times G$ & $6.023^{*}$ & .832 \\
\hline Ant & 1.890 & 2.675 \\
\hline Ant $\times G$ & .098 & 1.371 \\
\hline$S \times A$ & .543 & .309 \\
\hline$S \times A \times G$ & .109 & .006 \\
\hline$S \times L$ & .949 & 1.456 \\
\hline$S \times L \times G$ & .667 & .102 \\
\hline$A \times L$ & .962 & .240 \\
\hline$A \times L \times G$ & 1.856 & 1.517 \\
\hline$S \times A \times L$ & $31.017^{* * *}$ & $44.154^{* * *}$ \\
\hline $\mathrm{S} \times \mathrm{A} \times \mathrm{L} \times \mathrm{G}$ & 3.521 & 2.785 \\
\hline S $\times$ Ant & .131 & .012 \\
\hline$S \times A n t \times G$ & .219 & .383 \\
\hline$A \times A n t$ & .391 & 1.631 \\
\hline$A \times A n t \times G$ & .009 & 1.151 \\
\hline$S \times A \times A n t$ & $4.452^{*}$ & $6.506^{*}$ \\
\hline$S \times A \times A n t \times G$ & 1.493 & 2.716 \\
\hline$L \times A n t$ & $30.546^{* * *}$ & $17.941^{* * *}$ \\
\hline$L \times A n t \times G$ & $12.994^{* *}$ & $8.633^{* *}$ \\
\hline$S \times L \times A n t$ & 1.622 & 1.064 \\
\hline$S \times L \times A n t \times G$ & .000 & .384 \\
\hline$A \times L \times A n t$ & 3.964 & $30.887^{* * *}$ \\
\hline$A \times L \times A n t \times G$ & $6.137^{*}$ & $12.167^{* *}$ \\
\hline $\mathrm{S} \times \mathrm{A} \times \mathrm{L} \times \mathrm{Ant}$ & $37.203^{* * *}$ & $37.454^{* * *}$ \\
\hline $\mathrm{S} \times \mathrm{A} \times \mathrm{L} \times \mathrm{Ant} \times \mathrm{G}$ & .010 & .667 \\
\hline
\end{tabular}

$\mathrm{S}=$ status; $\mathrm{G}=$ group; $\mathrm{A}=$ agreement; $\mathrm{L}=$ laterality; $\mathrm{Ant}=$ anteriority. ${ }^{*} p<.05,{ }^{* *} p<.01,{ }^{* * *} p<.001$.

정을 실시한 결과, 좌측 후두영역에서 상대적 지위에 따른 일치성 간 차이가 유의하지 않은 반면, 좌측 전두영역에서 상대적 지위에 따른 일치성 간 차이가 유의하였다 $(p<.001)$. 우측 전두-후두영역 에서 상대적 지위에 따른 일치성 간 차이가 유의하였다 $(p<.05)$.

\section{논의 및 결론}

본 연구의 목적은 청자의 상대적 지위 및 서술어 종결어미 일치 여부에 따라 집단 간 정반응률 및 반응시간, ERP 성분의 평균진폭 크기에 차이가 있는지 보고자 하는 것이었다.

문장판단과제의 정반응률은 청년층의 평균 정반응률이 노년층
의 평균 정반응률보다 유의하게 더 높았다. 또한, 청년층의 경우 상 대적 지위에 따른 종결어미 일치성 간 정반응률의 차이가 유의하지 않은 반면, 노년층의 경우 상대적 지위에 따른 종결어미일치성 간 정반응률의 차이가 유의하였다. 문장판단과제의 반응 시간은 청년 층의 평균 반응시간이 노년층의 평균 반응시간에 비해 유의하게 더 빨랐다. 또한, 노년층에서 상대적 지위 간 반응시간의 차이가 청년 층에서 상대적 지위 간 반응시간의 차이에 비해 더 크게 나타났다.

$\mathrm{ERP}$ 분석에서는 동사 제시 후 300-500 ms 구간에서 집단 및 일 치성, 좌우측영역, 전두-후두영역 간 평균진폭의 차이가 유의하였 으며, 이는 청년층의 경우 종결어미 일치 조건 대비 불일치 조건에 서 좌측 전두-후두, 우측 후두영역 대비 우측 전두영역의 평균진폭 의 방향성이 노년층의 종결어미 불일치 조건 대비 일치 조건에서 좌측 전두-후두, 우측 후두영역 대비 우측 전두영역의 평균진폭의 방향성에 비해 더 크게 나타났기 때문이다. 즉, 경어법 처리과정에 서 선행하는 호칭어를 통해 나타나는 청자의 상대적 지위에 따라 예측되는 종결어미 사용이 적합하지 않아 어휘 처리과정에서 의미 통합의 실패로 인해 $\mathrm{N} 400$ 이 관찰되었다. 이는 한국어 경어법의 문 장 처리과정에서 호칭과 종결어미가 일치하지 않을 경우 $\mathrm{N} 400$ 이 관찰된 Kwak (2015)의 결과와 일치한다. 만다린 중국어의 경어법 발화 처리과정을 ERP 실험을 통해 살펴 본 Jiang 등(2013)의 결과 와도 일치한다. 대명사 nin-de로 공손한 표현을 사용하고 ni-de로 공손함이 덜 한 표현을 사용함으로써 지위에 따라 일치 문장, 불일 치 문장, 동등한 문장을 조건으로 구성하였다. 지위에 따라 대명사 의 공손함의 표현이 지위와 일치하지 않을 경우 $\mathrm{N} 400$ 이 관찰되었 다고 하였다. 또한, 뒤에 오는 선행사건에서 주어 대명사가 생략된 경어법 문장 처리과정을 살펴 본 Park 등(2015)의 결과와 일치한다. 선행 문장의 대명사 주어가 선행 문장 뒤에 오는 문장에서의 대명 사 주어에 따라 문장의 동사와 형용사에 선어말어미 '-시-'(honorific marker)를 사용하거나 사용하지 않음으로써 공손함과 공손하 지 않음을 표현하였다. 선행하는 주어의 지위에 대해 적합하지 않은 공손함의 표현을 사용하였을 경우 320-420 ms 구간에서 N400$\mathrm{N} 400$ 은 주로 두정부(정수리, centro-parietal) 부위에서 크게 나타 나며, 우반구에서 나타나는 경향이 있다고 알려져 있다(Kutas \& Federmeier, 2011)—이 관찰되었다. 선행된 문장에 낮은 지위를 갖 는 주어가 왔을 경우의 불일치 조건에서는 전두영역에서 부적(negativity) 성분이 관찰되었으며, 선행된 문장에 높은 지위를 갖는 주 어가 왔을 경우의 불일치 조건에서는 후두영역에서 부적 성분이 관 찰되었다.

또한, 본 논문에서 관찰된 $\mathrm{N} 400$ 은 의미 통합의 실패뿐만 아니라 문맥 오류로 인해서도 관찰될 수 있다. 한국어의 경어법은 의무적 
이며 화용적인 요소이다. 화용 지식, 세상 지식(world knowledge), 조사사용의 문법 규칙, 문장 구조와 구성성분의 위치로 경어법 문 장이 이루어지게 된다(Kwon \& Sturt, 2016). 담화의 문맥 오류나 화 자의 신분, 청자의 가치관과 같은 비언어적(extra-linguistic)인 요소 로 인해서도 $\mathrm{N} 400$ 이 관찰된다. 일본어 경어법 연구에서 상대방의 지위에 맞지 않게 경어를 사용했을 경우 맥락과 일치하지 않아 관 찰되는 N400을 보고한 선행연구의 결과와 일치한다(Sakai et al., 2014). 비언어적인 요소 중 사회적 지위 정보가 본 실험 문장에 조건 으로 설정되어 있다. 사회적 지위 정보를 통한 맥락 전후 관계에 대 한 지식은 발화를 이해하는데 사용된다. 사회적 지위 정보와 사회 적 지위 정보로 예측할 수 있는 사회적으로 관념화된 예측(stereotypical assumption)이 위반되었을 경우 N400이 나타난 선행논문 의 결과와 일치한다(Van Berkum, Van den Brink, Tesink, Kos, \& Hagoort, 2008; Van Den Brink et al., 2012). 의미적·화용적 오류에 서 N400이 나타나고, 화용 의미의 위반(pragmatic meaning anomalies)은 N400을 유발한다. 또한, 인종(Hehman, Volpert, \& Simons, 2014), 성별(White, Crite, Taylor, \& Corral, 2009), 개성(Baetens, Van der Cruyssen, Achtziger, Vandekerckhove, \& Van Overwalle, 2011), 사회 집단(Wang et al., 2011)과 같은 사회적 관념에 적합하지 않을 경우에도 N400이 관찰된다는 선행연구들이 있다. 즉, 화용적 인 요소에 의해 $\mathrm{N} 400$ 이 관찰되었다고 할 수 있다.

본 연구에서는 경어 형식과 관련되는 사회적 지위의 화용적인 위반에 대해 뇌가 다르게 반응하고 사회적 화용 맥락이 발화를 이 해하는데 있어서 고려되어진다는 것을 보여준다. 또한 사회적 지위 와 같은 사회적·화용적인 정보를 바탕으로 의미적 맥락(semantic context)을 파악함으로써 언어 이해가 이루어지는데 호칭을 통해 나타나는 청자의 상대적 지위 정보와 이에 적합한 종결어미 유형의 단어가 사용되어지지 않아 문맥 의미 과정(contextual meaning processing)에서의 화용적 오류로 인해 $\mathrm{N} 400$ 이 관찰되었다고 해석 할수 있다.

한편, 노년층에서도 경어법 문장 처리과정에서 호칭에서 나타나 는 상대적 지위에 부합하는 종결어미 유형을 사용하지 않는 경우 화용오류로 인한 어휘 처리과정의 실패로 부적(negative) 성분이 관 찰되었으나, 300-500 ms 구간에서 관찰된 청년층의 부적 성분보다 진폭의 크기가 작고 지속되어 관찰되었다. 이는 노화로 인해 인지 적 자원을 효율적으로 할당하는 능력이나 기억용량(capacity)이 감 소되어 전반적인 언어처리능력이 낮아지고 발화 내에서 문맥을 적 절히 유지하는 능력의 저하로 인한 것으로 해석할 수 있다.

노년층은 낮은 상대적 지위에서 높임 종결어미를 사용하여 일치 된 조건일 경우에 부적 성분이 관찰되었는데 본 논문에서는 이를
연령으로 인한 언어행동의 차이로 해석하였다. 언어행동은 개개인 이 지금까지 경험한 여러 사실이 축적되어 이루어지게 되며 이러한 경험적 사실을 개인적으로 내재화한 것이다( $\mathrm{Ha}, 2010)$. 또한 한국 인과 일본인의 경어의식에 관한 연구인 Hong (2002)에 의하면 일 본인은 장면이나 상황을 기준으로 경어 표현을 사용하고 한국인은 상대방의 연령을 중요한 기준으로 하여 경어 표현을 사용한다고 하 였다. 한국인은 연장자에 대한 상하경어의식이 높으며 화자와 연령 적으로 많은 차이가 날 때 적용되는 것으로 나타났다. 이에 따라서 낮은 청자의 지위에 높임 종결어미를 사용하여 문장이 불일치하는 조건에서 노년층의 정반응률 및 반응시간에 유의한 차이가 나타난 것으로 해석할 수 있다.

동사 제시 후 500-800 ms 구간에서 일치성, 좌우측영역, 전두-후 두영역 간 평균진폭의 차이가 유의하였으며 이는 종결어미 불일치 조건에서 좌우측영역에 따른 전두-후두영역 간 평균진폭의 방향성 이 종결어미 일치 조건에서 좌우측영역에 따른 전두-후두영역 간 평균진폭의 방향성에 비해 더 크게 나타났기 때문이다. 즉, 경어법 처리과정에서 좌측 전두영역에서 $\mathrm{P} 600$ 이 관찰되었으며 선행하는 호칭어를 통해 나타나는 청자의 상대적 지위에 따라 예측되는 종결 어미 사용이 적합하지 않아 통사적 오류로 인해 $\mathrm{P} 600$ 이 관찰되었 다. 뒤에 오는 선행사건에서 주어 대명사가 생략된 경어법 문장 처 리과정을 살펴 본 Park 등(2015)의 결과와 일치한다. 선행하는 주어 의 지위에 대해 동사/형용사를 적합하지 않은 공손함의 표현을 사 용하였을 경우 전두영역에서 정적(positivity) 방향으로 성분이 나 타났다. 사회적 요소에 영향을 받는 의미적·화용적 처리과정인 경 어법은 의미·화용적 요소뿐만 아니라 통사적인 요소도 가지고 있 다(Boeckx \& Niinuma, 2004; Gunji, 1987; Harada, 1976; Ivana \& Sakai, 2007). 통사적 위반을 반영하는 P600 성분은 주어-동사 경 어 일치(subject-verb honorification agreement)가 위반되었을 때 나타난다고 하였다(Osterhout \& Nicol, 1999). 통사 처리(syntactic operation)는 보편문법에 의해 만들어지며 언어를 사용할 수 있게 해준다(Chomsky, 2000). 만다린 중국어의 경어법 발화 처리과정 을 ERP 실험을 통해 살펴본 Jiang 등(2013)의 결과와도 일치한다. 지위에 따라 대명사의 공손함의 표현이 지위와 일치하지 않을 경우 500-1,800 ms 구간에서 지속된 정적(positivity) 성분이 나타났다. 청년층의 경우 300-500 ms 구간에서는 N400 성분이 관찰되었고, 500-800 ms 구간에서는 P600 성분이 관찰되었다. 한편, 노년층은 정적(positivity) 성분이 나타나지 않았다. 청년층도 P600 성분이 관 찰되긴 하였지만 N400 성분에 비해 강하게 나타나지 않았다. 본 논 문에서는 경어법 문장 처리과정이 문법·통사적 요소와 화용적 측 면도 가지고 있어 문맥 의미 과정(contextual meaning processing) 
을 통해 문장이 처리된다고 해석할 수 있다. 본 논문은 ERP를 사용 하여 실시간 문장처리 분석을 통해 경어법과 관련된 문법 처리과정 에서 나타나는 노화에 따른 변화를 관찰할 수 있었다. 이와 같이 $\mathrm{ERP}$ 를 언어병리학적 패러다임에 적용함으로써 오프라인 과제를 통한 평가만으로는 한계가 있는 부분을 보완할 수 있다는 점에서 의미가 있다. 실시간 언어처리 분석을 통해 노화와 관련된 문장 처 리 손상을 조기에 감지할 수 있으며, 이를 기반으로 차후 다양한 언 어중재 프로그램을 개발하는데 기초자료를 제공할 수 있다는 점에 서 임상적 의의가 있다.

본 논문은 문장을 사용하는 상황의 격식성(formality)과 친근감 (social distance)을 조건으로는 설정하지 않았다는 제한점이 있다. 전제되는 상황의 격식성 및 거리감의 정도에 따라 경어법의 사용이 달라질 수 있으며, Lee (2011)에 따르면 경어법에는 윗사람이 아랫 사람에게 지위 관계를 따지지 않고 높임 형식을 씀으로써 공손함 을 드러낼 수 있는 '공손한 태도 드러내기' 기능이 있다고 하였다. 또 한, 경어법 처리는 사회적인 맥락 요소가 포함되어 있으므로 성별 에 따른 차이도 고려해야 될 부분이다. 따라서 향후 연구에 대한 제 언으로는 격식성 및 화자와 청자 관계에서 친밀감의 정도에 의한 경어 표현 사용의 기능과 성별의 비율도 고려하여 연구가 이루어질 필요가 있다.

\section{REFERENCES}

Agha, A. (2007). Language and social relations. Cambridge: Cambridge University Press.

Baetens, K., Van der Cruyssen, L., Achtziger, A., Vandekerckhove, M., \& Van Overwalle, F. (2011). N400 and LPP in spontaneous trait inferences. Brain Research, 1418, 83-92.

Bialystok, E., \& Poarch, G. J. (2014). Language experience changes language and cognitive ability. Zeitschrift für Erziehungswissenschaft, 17, 433-446.

Boeckx, C., \& Niinuma, F. (2004). Conditions on agreement in Japanese. Natural Language \& Linguistic Theory, 22, 453-480.

Caplan, D., DeDe, G., Waters, G., Michaud, J., \& Tripodis, Y. (2011). Effects of age, speed of processing, and working memory on comprehension of sentences with relative clauses. Psychology and Aging, 26, 439-450.

Chomsky, N. (2000). New horizons in the study of language and mind. New York, NY: Cambridge University Press.

Frattali, C., \& Lynch, C. (1989). Functional assessment: current issues and future challenges. Asha, 31, 70-74.

Friederici, A. D., \& Weissenborn, J. (2007). Mapping sentence form onto mean- ing: the syntax-semantic interface. Brain Research, 1146, 50-58.

Gunji, T. (1987). Japanese Phrase Structure Grammar: a unification-based approach. Dordrecht: Springer.

Gunter, T. C., Jackson, J. L., \& Mulder, G. (1992). An electrophysiological study of semantic processing in young and middle-aged academics. Psychophysiology, 29, 38-54.

Gunter, T. C., Jackson, J. L., \& Mulder, G. (1996). Focussing on aging: an electrophysiological exploration of spatial and attentional processing during reading. Biological Psychology, 43, 103-145.

Ha, C. G. (2010). A study on the correlation between linguistic competence and cognitive abilities. HAN-GEUL, (287), 5-43.

Hagoort, P., Wassenaar, M., \& Brown, C. M. (2003). Syntax-related ERP-effects in Dutch. Cognitive Brain Research, 16, 38-50.

Harada, S. I. (1976). Honorifics. Syntax and Semantics, 5, 499-561.

Harbin, T. J., Marsh, G. R., \& Harvey, M. T. (1984). Differences in the late components of the event-related potential due to age and to semantic and non-semantic tasks. Electroencephalography and Clinical Neurophysiology/ Evoked Potentials Section, 59, 489-496.

Hehman, E., Volpert, H. I., \& Simons, R. F. (2014). The N400 as an index of racial stereotype accessibility. Social Cognitive and Affective Neuroscience, 9, 544-552.

Hong, M. P. (2002). A sociolinguistic study on politeness consciousness of Japanese and Korean. Journal of Japanese Language and Literature, 41, 193211.

Howieson, D. B., Loring, D. W., \& Hannay, H. J. (2004). Neurobehavioral variables and diagnostic issues. In M. D. Lezak et al. (Eds.), Neuropsychological assessment (4th ed., pp. 286-336). New York, NY: Oxford University Press.

Ivana, A., \& Sakai, H. (2007). Honorification and light verbs in Japanese. Journal of East Asian Linguistics, 16, 171-191.

Jasper, H. H. (1958). The ten twenty electrode system of the international federation. Electroencephalography and Clinical Neurophysiology, 10, 371-375.

Jiang, X., Li, Y., \& Zhou, X. (2013). Is it over-respectful or disrespectful? Differential patterns of brain activity in perceiving pragmatic violation of social status information during utterance comprehension. Neuropsychologia, 51, 2210-2223.

Jung, I. K., Kwak, D. I., Joe, S. H., \& Lee, H. S. (1997). A study of standardization of Korean form of Geriatric Depression Scale (KGDS). Journal of Korean Geriatric Psychiatry, 1, 61-72.

Kang, Y. (2006). A normative study of the Korean-Mini Mental State Examination (K-MMSE) in the elderly. Korean Journal of Psychology: General, 
$25,1-12$.

Kang, Y., Jang, S. M., \& Na, D. L (2012). Seoul Neuropsychological Screening Battery (2nd ed.). Seoul: Human Brain Research \& Consulting.

Kang, Y., Na, D. L., \& Hahn, S. (1997). A validity study on the Korean MiniMental State Examination (K-MMSE) in dementia patients. Journal of the Korean Neurological Association, 15, 300-308.

Kavanagh, K. H., \& Kennedy, P. H. (1992). Promoting cultural diversity: strategies for health care professionals. Newbury Park, CA: Sage Publications.

Kemtes, K. A., \& Kemper, S. (1999). Aging and resolution of quantifier scope effects. The Journals of Gerontology Series B: Psychological Sciences and Social Sciences, 54, P350-P360.

Kim, T. (2007). A study on the hearer-honorific system of modern Korean EOMUNHAK, 96, 1-20.

King, J. W., \& Kutas, M. (1995). Who did what and when? Using word-and clause-level ERPs to monitor working memory usage in reading. Journal of Cognitive Neuroscience, 7, 376-395.

Kutas, M., \& Federmeier, K. D. (2011). Thirty years and counting: finding meaning in the N400 component of the event-related brain potential (ERP). Annual Review of Psychology, 62, 621-647.

Kutas, M., \& Iragui, V. (1998). The N400 in a semantic categorization task across 6 decades. Electroencephalography and Clinical Neurophysiology/ Evoked Potentials Section, 108, 456-471.

Kwak, J. (2015). Influence of formality of the dialogue situation on Korean honorific sentence processing: an event-related potential study (Master's thesis). Pusan National University, Busan, Korea.

Kwon, N., \& Sturt, P. (2016). Attraction effects in honorific agreement in Korean. Frontiers in Psychology, 7, 1-13.

Lee, J. B. (2011). Major functions of Korean honorifics. Korean Language and Literature, 52, 25-53.

Lee, M. S. (2015). A longitudinal study on cognitive-pragmatic language in normal aging: demographic \& experiential Influences. Journal of the Korean Gerontological Society, 35, 797-811.

Lee, M. S., \& Kim, H. H. (2012). Cognitive-pragmatic language assessment for normal aging: study of assessment tools and content validity. Journal of the Korea Contents Association, 12, 280-292.

Luck, S. J. (2014). An introduction to the event-related potential technique (2nd ed.). Cambridge, MA: MIT Press.

Martín-Loeches, M., Muñoz, F., Casado, P., Melcon, A., \& Fernández-Frías,
C. (2005). Are the anterior negativities to grammatical violations indexing working memory? Psychophysiology, 42, 508-519.

Martin, S. E. (1992). A reference grammar of Korean: a complete guide to the grammar and history of the Korean language. Tokyo: Tuttle Publishing.

Matzke, M., Mai, H., Nager, W., Rüsseler, J., \& Münte, T. (2002). The costs of freedom: an ERP-study of non-canonical sentences. Clinical Neurophysiology, 113, 844-852.

Osterhout, L., \& Nicol, J. (1999). On the distinctiveness, independence, and time course of the brain responses to syntactic and semantic anomalies. Language and Cognitive Processes, 14, 283-317.

Park, M. K., Cho, E., \& Chung, W. (2015). Backward antecedent search of the null subject pronominal (pro) in Korean. Language Research, 51, 537-568.

Sakai, H., Long, S., Luo, Y., \& Sato, M. (2014). Computation for syntactic dependency at language-culture interface: a view from Japanese honorific processing. International Journal of Psychophysiology, 2, 179-179.

Van Berkum, J. J. (2009). The neuropragmatics of 'simple' utterance comprehension: an ERP review. In U. Sauerland \& K. Yatsushiro (Eds.), Semantics and pragmatics: from experiment to theory (pp. 276-316). Basingstoke: Palgrave Macmillan.

Van Berkum, J. J., Van den Brink, D., Tesink, C. M., Kos, M., \& Hagoort, P. (2008). The neural integration of speaker and message. Journal of Cognitive Neuroscience, 20, 580-591.

Van den Brink, D., Van Berkum, J. J., Bastiaansen, M. C., Tesink, C. M., Kos, M., Buitelaar, J. K., \& Hagoort, P. (2012). Empathy matters: ERP evidence for inter-individual differences in social language processing. Social Cognitive and Affective Neuroscience, 7, 173-183.

Wang, L., Ma, Q., Song, Z., Shi, Y., Wang, Y., \& Pfotenhauer, L. (2011). N400 and the activation of prejudice against rural migrant workers in China. Brain Research, 1375, 103-110.

Wang, Y. (2013). A study of teaching method on terms of address in Korean language for the Chinese learners (Master's thesis). Inha University, Incheon, Korea.

White, K. R., Crites, S. L., Taylor, J. H., \& Corral, G. (2009). Wait, what? Assessing stereotype incongruities using the N400 ERP component. Social Cognitive and Affective Neuroscience, 4, 191-198.

Woodward, S. H., Ford, J. M., \& Hammett, S. C. (1993). N4 to spoken sentences in young and older subjects. Electroencephalography and Clinical Neurophysiology, 87, 306-320. 
Appendix 1. 실험 문장

\begin{tabular}{|c|c|c|}
\hline 청자의 지위 & & \\
\hline 종결어미 일치성 & 일치 & 불일치 \\
\hline 실험 문장 & 교수님, 주문을 취소했습니다 & 교수님, 주문을 취소했어 \\
\hline & 선생님, 상황을 알아봤습니다 & 선생님, 상황을 알아봤어 \\
\hline & 회장님, 서류를 작성했습니다 & 회장님, 서류를 작성했어 \\
\hline & 사장님, 책상을 정리했습니다 & 사장님, 책상을 정리했어 \\
\hline & 원장님, 일정을 변경했습니다 & 원장님, 일정을 변경했어 \\
\hline & 박사님, 문제를 풀었습니다 & 박사님, 문제를 풀었어 \\
\hline & 팀장님, 물건을 실었습니다 & 팀장님, 물건을 실었어 \\
\hline & 이사님, 식당을 예약했습니다 & 이사님, 식당을 예약했어 \\
\hline & 대리님, 메뉴를 정했습니다 & 대리님, 메뉴를 정했어 \\
\hline & 대표님, 부품을 고쳤습니다 & 대표님, 부품을 고쳤어 \\
\hline & 교수님, 포장을 뜯었습니다 & 교수님, 포장을 뜯었어 \\
\hline & 선생님, 행사를 계획했습니다 & 선생님, 행사를 계획했어 \\
\hline & 회장님, 사건을 해결했습니다 & 회장님, 사건을 해결했어 \\
\hline & 사장님, 휴지를 주웠습니다 & 사장님, 휴지를 주웠어 \\
\hline & 원장님, 청소를 시작했습니다 & 원장님, 청소를 시작했어 \\
\hline & 박사님, 바닥을 쓸었습니다 & 박사님, 바닥을 쓸었어 \\
\hline & 팀장님, 사진을 찍었습니다 & 팀장님, 사진을 찍었어 \\
\hline & 이사님, 상자를 옮겼습니다 & 이사님, 상자를 옮겼어 \\
\hline & 대리님, 창문을 닫았습니다 & 대리님, 창문을 닫았어 \\
\hline & 대표님, 서랍을 열었습니다 & 대표님, 서랍을 열었어 \\
\hline
\end{tabular}

\begin{tabular}{|c|c|c|}
\hline 청자의 지위 & & \\
\hline 종결어미 일치성 & 일치 & 불일치 \\
\hline 실험 문장 & $\begin{array}{l}\text { 현지야, 주문을 취소했어 } \\
\text { 승희야, 상황을 알아봤어 } \\
\text { 영희야, 서류를 작성했어 } \\
\text { 수희야, 책상을 정리했어 } \\
\text { 민수야, 일정을 변경했어 } \\
\text { 성규야, 문제를 풀었어 } \\
\text { 민주야, 물건을 실었어 } \\
\text { 진희야, 식당을 예약했어 } \\
\text { 연주야, 메뉴를 정했어 } \\
\text { 철수야, 부품을 고쳤어 } \\
\text { 현지야, 포장을 뜯었어 } \\
\text { 승희야, 행사를 계획했어 } \\
\text { 영희야, 사건을 해결했어 } \\
\text { 수희야, 휴지를 주웠어 } \\
\text { 민수야, 청소를 시작했어 } \\
\text { 성규야, 바닥을 쓸었어 } \\
\text { 민주야, 사진을 찍었어 } \\
\text { 진희야, 상자를 옮겼어 } \\
\text { 연주야, 창문을 닫았어 } \\
\text { 철수야, 서랍을 열었어 }\end{array}$ & $\begin{array}{l}\text { 현지야, 주문을 취소했습니다 } \\
\text { 승희야, 상황을 알아봤습니다 } \\
\text { 영희야, 서류를 작성했습니다 } \\
\text { 수희야, 책상을 정리했습니다 } \\
\text { 민수야, 일정을 변경했습니다 } \\
\text { 성규야, 문제를 풀었습니다 } \\
\text { 민주야, 물건을 실었습니다 } \\
\text { 진희야, 식당을 예약했습니다 } \\
\text { 연주야, 메뉴를 정했습니다 } \\
\text { 철수야, 부품을 고쳤습니다 } \\
\text { 현지야, 포장을 뜯었습니다 } \\
\text { 승희야, 행사를 계획했습니다 } \\
\text { 영희야, 사건을 해결했습니다 } \\
\text { 수희야, 휴지를 주웠습니다 } \\
\text { 민수야, 청소를 시작했습니다 } \\
\text { 성규야, 바닥을 쓸었습니다 } \\
\text { 민주야, 사진을 찍었습니다 } \\
\text { 진희야, 상자를 옮겼습니다 } \\
\text { 연주야, 창문을 닫았습니다 } \\
\text { 철수야, 서랍을 열었습니다 }\end{array}$ \\
\hline
\end{tabular}




\section{국문초록}

\section{청자-화자 지위관계 및 종결어미 일치 여부에 따라 경어법 문장처리과정에서 나타나는 청년층 및 노년층 간 ERP 성분 차이 분석}

\section{오선정 - 성지은}

이화여자대학교 대학원 언어병리학과

배경 및 목적: 한국어가 가지는 언어형식인 경어법 처리과정을 청년층과 노년층을 대상으로 ERP 실험을 통해 살펴보고자 한다. 방법: 청년층 23명(만20-40세), 노년층 21명(만60-80세), 총 44명이 본 연구에 참여하였다. 실험 문장은 ‘호칭+목적어+서술어' 3어절 문장으 로, 서술어 종결어미를 변화시켜 구성하였다. 호칭에서 나타나는 높고, 낮은 지위수준에 대한 종결어미 일치 여부에 따라 실험 조건에 사용된 문장은 총 4 가지 유형이다. 높은 상대적 지위와 종결어미 일치 조건, 높은 상대적 지위와 종결어미 불일치 조건, 낮은 상대적 지 위와 종결어미 일치 조건, 낮은 상대적 지위와 종결어미 불일치 조건으로 구성되었다. 결과: 문장판단과제에서 노년층이 청년층에 비해 정반응률이 낮고, 반응시간이 길어지는 현상을 보였다. ERP 분석에서 청년층은 종결어미 불일치 조건에서 300-500 ms 구간에서 N400 성분과 500-800 ms 구간에서 P600 성분이 관찰되었다. 노년층은 300-500 ms 구간에서 N400 성분이 관찰되었으나 청년층에 비해 진 폭의 크기가 작고 지속되어 나타났으며 P600 성분은 관찰되지 않았다. 논의 및 결론: 화용 맥락과 의미 통합 실패를 야기하는 종결어 미 불일치조건에서 N400 성분이 관찰되었으며, 화용적 요소뿐만 아니라 통사적 요소도 가지고 있는 경어법은 통사 오류로 인해 P600 이 나타난 것으로 해석된다. 노년층은 노화로 인해 인지능력이나 기억용량이 감소되어 언어처리능력이 낮아지고 발화 문맥을 유지하는 능력의 저하로 인한 것으로 해석할 수 있다.

핵심어: 노년층, 경어법, $\mathrm{ERP}, \mathrm{N} 400, \mathrm{P} 600$, 문장처리

이 논문은 2016년 대한민국 교육부와한국연구재단의 지원을 받아 수행된 연구임(NRF-2016S1A5B6913884).

이 논문은 2016년 한국언어청각임상학회 이승환장학금 지원에 의한 연구임.

\section{참고문헌}

강연욱(2006). K-MMSE (Korean-Mini Mental State Examination)의 노인 규준 연구. 한국심리학회지: 일반, 25, 1-12.

강연욱, 나덕렬, 한승혜(1997). 치매환자들을 대상으로 한 K-MMSE의 타당도연구. 대한신경과학회지, 15, 300-308.

강연욱, 장승민, 나덕렬(2012). 서울신경심리검사 2판. 서울: 휴브알엔씨.

곽자랑(2015). 대화상황의 격식성이 한국어 경어법 문장 처리에 미치는 효과: 사건관련전위 연구. 부산대학교 석사학위논문.

김태엽(2007). 국어 청자대우법의 체계화 문제. 어문학, 96, 1-20.

왕운(2013). 중국인 학습자를 위한 한국어 호칭어 교육 방안 연구. 인하대학교 석사학위논문.

이미숙(2015). 노년층의 인지-화용언어 능력에 관한 종단 연구: 영향 요인들을 중심으로. 한국노년학, 35, 797-811.

이미숙, 김향희(2012). 노년층의 인지-화용언어 능력 평가. 한국콘텐츠학회논문지, 12, 280-292.

이정복(2011). 한국어 경어법의 주요 기능 우리말글, 52, 25-53.

정인과, 곽동일, 조숙행, 이현수(1997). 한국형 노인우울검사(Korean Form of Geriatric Depression Scale; KGDS) 표준화 연구. 노인정신의학, 1, 61-

72.

하치근(2010). 언어능력과 인지능력의 상관관계. 한글, (287), 5-43.

홍민표(2002). 문학, 일본학 편: 한국인과 일본인의 경어의식에 대한 사회언어학적 연구. 일어일문학연구, 41, 193-211. 